\title{
The unexpected explosive sub-Plinian eruption of Calbuco volcano (22-23 April 2015; southern Chile): Triggering mechanism implications
}

DOI:

10.1016/j.jvolgeores.2019.04.006

\section{Document Version \\ Accepted author manuscript}

Link to publication record in Manchester Research Explorer

Citation for published version (APA):

Arzilli, F., Morgavi, D., Petrelli, M., Polacci, M., Burton, M., Di Genova, D., Spina, L., La Spina, G., Hartley, M. E., Romero, J. E., Fellowes, J., Diaz-alvarado, J., \& Perugini, D. (2019). The unexpected explosive sub-Plinian eruption of Calbuco volcano (22-23 April 2015; southern Chile): Triggering mechanism implications. Journal of Volcanology and Geothermal Research, 378, 35-50. https://doi.org/10.1016/j.jvolgeores.2019.04.006

\section{Published in:}

Journal of Volcanology and Geothermal Research

\section{Citing this paper}

Please note that where the full-text provided on Manchester Research Explorer is the Author Accepted Manuscript or Proof version this may differ from the final Published version. If citing, it is advised that you check and use the publisher's definitive version.

\section{General rights}

Copyright and moral rights for the publications made accessible in the Research Explorer are retained by the authors and/or other copyright owners and it is a condition of accessing publications that users recognise and abide by the legal requirements associated with these rights.

\section{Takedown policy}

If you believe that this document breaches copyright please refer to the University of Manchester's Takedown Procedures [http://man.ac.uk/04Y6Bo] or contact uml.scholarlycommunications@manchester.ac.uk providing relevant details, so we can investigate your claim.

\section{OPEN ACCESS}




\section{Accepted Manuscript}

The unexpected explosive sub-Plinian eruption of Calbuco volcano (22-23 April 2015; southern Chile): Triggering mechanism implications

Fabio Arzilli, Daniele Morgavi, Maurizio Petrelli, Margherita Polacci, Mike Burton, Danilo Di Genova, Laura Spina, Giuseppe La Spina, Margaret E. Hartley, Jorge E. Romero, Jonathan

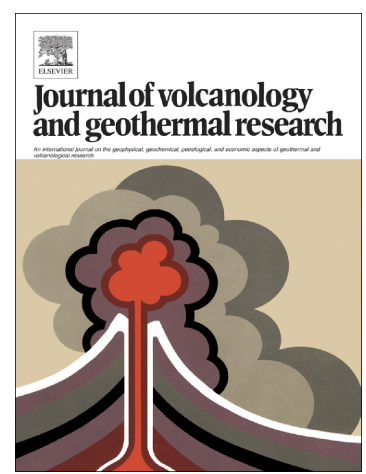
Fellowes, Juan Diaz-Alvarado, Diego Perugini

PII: S0377-0273(18)30560-2

DOI: https://doi.org/10.1016/j.jvolgeores.2019.04.006

Reference: VOLGEO 6593

To appear in: Journal of Volcanology and Geothermal Research

Received date: $\quad 12$ December 2018

Revised date: $\quad 5$ April 2019

Accepted date: $\quad 9$ April 2019

Please cite this article as: F. Arzilli, D. Morgavi, M. Petrelli, et al., The unexpected explosive sub-Plinian eruption of Calbuco volcano (22-23 April 2015; southern Chile): Triggering mechanism implications, Journal of Volcanology and Geothermal Research, https://doi.org/10.1016/j.jvolgeores.2019.04.006

This is a PDF file of an unedited manuscript that has been accepted for publication. As a service to our customers we are providing this early version of the manuscript. The manuscript will undergo copyediting, typesetting, and review of the resulting proof before it is published in its final form. Please note that during the production process errors may be discovered which could affect the content, and all legal disclaimers that apply to the journal pertain. 
The unexpected explosive sub-Plinian eruption of Calbuco volcano (22-23 April 2015; southern Chile): triggering mechanism implications

Fabio Arzilli ${ }^{\mathrm{a}^{*}}$, Daniele Morgavi ${ }^{\mathrm{b}}$, Maurizio Petrelli ${ }^{\mathrm{b}}$, Margherita Polacci $^{\mathrm{a}}$, Mike Burton ${ }^{\mathrm{a}}$, Danilo Di Genova $^{c}$, Laura Spina ${ }^{\mathrm{d}}$, Giuseppe La Spina ${ }^{\mathrm{a}}$, Margaret E. Hartley ${ }^{\mathrm{a}}$, Jorge E. Romero ${ }^{\mathrm{e}}$ Jonathan Fellowes ${ }^{\mathrm{a}}$, Juan Diaz-Alvarado ${ }^{\mathrm{e}}$ and Diego Perugini ${ }^{\mathrm{b}}$

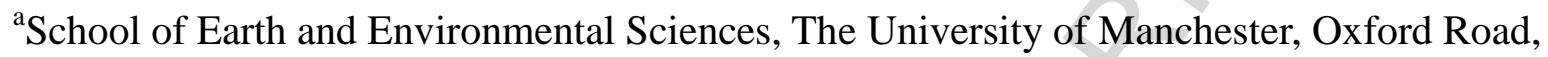
Manchester, M13 9PL, UK

${ }^{\mathrm{b}}$ Department of Physics and Geology, University of Perugia, Piazza dell'Università, 06123 Perugia, Italy

${ }^{\mathrm{c}}$ Institute of Non-Metallic Materials, Clausthal University of Technology, Zehntner Str. 2a, 38678 Clausthal-Zellerfeld, Germany

${ }^{\mathrm{d}}$ Istituto Nazionale di Geofisica e Vulcanologia, Via di Vigna Murata 605, 00143 Roma, Italy ${ }^{e}$ Departamento de Geología, Universidad de Atacama, Av. Copayapu 485, Copiapó, Chile

*Corresponding author: Dr. Fabio Arzilli

Corresponding author present affiliation: School of Earth and Environmental Sciences, The University of Manchester, Oxford Road, Manchester, M13 9PL, UK

E-mail address: fabio.arzilli@manchester.ac.uk

Phone: $+393298429732 ;+447904104670$

Keywords: Calbuco; Sub-Plinian eruption; Internal trigger; Crystallisation; Volcanic hazard 


\section{Abstract}

Plinian-type eruptions are extremely hazardous, producing pyroclastic fallout and flows extending many kilometres from the vent. The most commonly invoked eruption trigger for Plinian-type eruptions is the intrusion of fresh magma, generally associated with precursory ground deformation and seismicity days/weeks before eruption. Closed-system internal triggering has also been proposed, such as protracted crystallisation of magma, which can produce a build-up of exsolved volatiles and thus pressurise the system prior to eruption. On 22-23 April 2015 Calbuco volcano, Chile, produced a sub-Plinian eruption with $<3$ hours seismic precursory activity and no clear deformation signals in the preceding months. Here, we show that petrological and geochemical evidence do not support a hypothesis of eruption triggering due to pre-eruptive intrusion of fresh magma, but instead are consistent with an internal trigger. We found that basaltic andesitic magma was stored at depths between 8 and 12 km (i.e. 230-320 MPa) beneath Calbuco volcano before the 2015 eruption. The stored magma had an initial temperature of $900-950^{\circ} \mathrm{C}$, was water-saturated (5.5-6.5 wt. $\left.\% \mathrm{H}_{2} \mathrm{O}\right)$ and formed phenocrysts of titanomagnetite, orthopyroxene, clinopyroxene and plagioclase cores $\left(\mathrm{An}_{78-93}\right)$. Gradual cooling of the magma chamber produced thermal gradients and magma convection, evidenced by plagioclase overgrowth rims $\left(\mathrm{An}_{58-77}\right)$ and blocky microlites $(25-250 \mu \mathrm{m})$. Our interpretation is that this continuing crystallisation induced second boiling and an overpressurisation of the system, leading to the rapid onset of the 2015 eruption. Petrological and geochemical evidence therefore shows that a closed-system magma chamber can evolve into a highly explosive eruption with very little precursory warning, posing a challenge for current volcano monitoring paradigms. We propose that internal triggering should be carefully considered as a mechanism for unexpected sub-Plinian eruptions, prompting a potential revision of existing hazard management strategies. 


\section{Introduction}

Plinian-type eruptions are the largest explosive volcanic events in terms of their mass discharge rate (intensity) and erupted magma volume (magnitude) (Walker, 1980). The temporal recurrence of sub-Plinian eruptions $\left(0.1-1.0 \mathrm{~km}^{3}\right.$ ejecta volume, $>10 \mathrm{~km}$ plume height $)$ is about every year on Earth, while Plinian eruptions $\left(1.0-10.0 \mathrm{~km}^{3}\right.$ ejecta volume, $>20 \mathrm{~km}$ plume height) occur about every decade, and therefore together they produce significant volcanic hazards (Newhall and Self, 1982). The explosivity of Plinian-type eruptions generally requires volatile-rich and high viscosity magmas. Usually, these types of eruptions are associated with evolved calc-alkaline (andesite to rhyolite; Castro and Dingwell, 2009; Castro et al., 2013) and alkaline (trachyte to phonolite; Signorelli et al., 1999) magmas, although there are some rare exceptions of basaltic Plinian eruptions (e.g. Houghton et al., 2004; Walker et al., 1984).

The triggering mechanisms for large explosive eruptions are difficult to constrain and are the subject of considerable debate (Caricchi et al., 2014; Malfait et al., 2014; Gregg et al., 2015; Gudmundsson, 2016). These can be broadly grouped into five overlapping categories: (i) Injection of volatile-rich magmas into a more evolved magma chamber, which is the most commonly invoked triggering mechanism (Blake, 1981; Williams and Self, 1983; Walker et al., 1984; Pallister et al., 1992; de Silva et al., 2008; Sigmundsson et al., 2010; Wehrmann et al., 2016; Cassidy et al., 2016); (ii) Magma mixing following mafic magma injection (Sparks et al., 1977; Leonard et al., 2002; Stock et al., 2012; Macías et al., 2017); (iii) generation of overpressure due exsolution of volatiles via second boiling due to protracted crystallisation (Stock et al., 2016; Tramontano et al., 2017); (iv) perturbation of magmatic reservoirs close to a critical state by tectonic earthquakes (Linde and Sacks, 1998); (v) sector collapse of a volcanic edifice (e.g. Mount St Helens in 1980; Lipman and Mullineaux, 1981). 
Most volcanic eruptions are preceded by a period of volcanic unrest, marked by particular patterns of seismicity, gas emission, and ground deformation providing opportunities for eruption forecasting (Gorshkov and Dubik, 1970; Chouet et al., 1994; Chouet, 1996; Harlow et al., 1991; Sigmundsson et al., 2010; Aiuppa et al., 2010; Tarasewicz et al., 2014; White and McCausland, 2016; Riveira et al., 2017). The alert period for most eruptions is measured in weeks to months, where an increase in seismic activity may signal a greater likelihood of an eruption. The alert period can be as short as a few hours before eruption onset, leaving insufficient time to draw up actions for minimizing volcanic risk (Castro et al., 2013).

Improved knowledge of the pre-eruptive conditions and triggering mechanisms of Pliniantype events is of paramount importance for volcanologists to provide better short-term forecasts of eruption onset and hence mitigate hazardous situations (Sparks, 2003; Segall, 2013; Tramontano et al., 2017). The aim of this study is to better understand the conditions and mechanisms leading to the onset of Plinian-type eruptions, especially those that are preceded by only short periods of volcanic unrest. We focus on a case study, using petrological, geochemical and seismic data to constrain the pre- and syn-eruptive conditions of the 22-23 April 2015 subPlinian eruption of Calbuco volcano, southern Chile (Supplementary Fig. 1).

After 54 years of quiescence since its last sub-Plinian eruption in 1961, Calbuco volcano erupted on 22 April 2015 at 21:05 GMT (18:05 local time) near the cities of Puerto Montt, Puerto Varas and Ensenada, inhabited by a total of $\sim 260,000$ people. Calbuco volcano has been monitored by two seismometers since 2009, and a tiltmeter is located at $4 \mathrm{~km}$ west of the summit. The eruption started suddenly with only $\sim 3$ hours of precursory seismic activity. Preeruptive deformation was not detected by the tiltmeter nor observed in InSAR interferograms up to one day before the eruption (SERNAGEOMIN, 2015; Valderama et al., 2015; Delgado et al., 2017). Delgado et al. (2017) discussed that pre-eruptive deformation may have not been detected if it was lower than the background noise. Only co-eruptive deformation was detected 
during the eruption (Delgado et al., 2017). The first eruptive phase generated an eruptive column which reached a height of $\sim 15 \mathrm{~km}$ above the crater level and lasted $\sim 1.5$ hours (SERNAGEOMIN, 2015; Romero et al., 2016; Van Eaton et al., 2016; Castruccio et al., 2016; Pardini et al., 2018). After a pause of 5.5 hours, a second and more energetic eruptive phase started on 23 April at 04:08 GMT (01:08 local time) and lasted for 6 hours, developing an eruptive column >15 km above the crater level (SERNAGEOMIN, 2015; Romero et al., 2016; Van Eaton et al., 2016; Castruccio et al., 2016).

The total erupted volume has been estimated in four articles as $0.27 \mathrm{~km}^{3}$ (Romero et al., 2016), $0.38 \mathrm{~km}^{3}$ (Castruccio et al., 2016), $0.48 \mathrm{~km}^{3}$ (Pardini et al., 2018, assuming $1000 \mathrm{~kg} / \mathrm{m}^{3}$ density) and $0.56 \mathrm{~km}^{3}$ (Van Eaton et al., 2016). Of this total volume, 38\% was erupted during the first phase of the eruption and $62 \%$ during the second phase. The eruption has been classified as a sub-Plinian type event, according to the pyroclastic fall deposit (Romero et al., 2016; Castruccio et al., 2016). The magma bulk composition was basaltic andesite (Romero et al., 2016).

The Calbuco 2015 eruption is an important case study as it produced a strong sub-Plinian eruption with minimal eruption precursors, posing a significant challenge for risk managers. The purpose of this paper is to examine the processes that may produce such eruptions.

\section{Methods}

\subsection{Fieldwork}

Fall deposits at proximal and medial distances from the vent were sampled during fieldwork on 2-10 June 2015. Four main tephra units have been recognised within the eruptive sequence (units A, B, C, and D; see Fig. 1). Here we present analyses of basaltic andesite scoriae collected in two of the proximal fall deposits: DF-2, $\sim 6 \mathrm{~km}$ from the vent, and DF-10, $\sim 4 \mathrm{~km}$ from the vent (Romero et al., 2016). 


\subsection{Scanning Electron Microscopy (SEM) and textural analysis}

Back-scattered electron (BSE) images were collected using a JEOL JSM-6390LA FE-SEM at the School of Earth and Environmental Sciences, University of Manchester (UK), using an acceleration voltage of $15 \mathrm{kV}$ and beam current of $10 \mathrm{nA}$.

Textural analysis on BSE images was performed using ImageJ software. 2D image analysis was performed to measure the area of each phase (crystal phases, matrix glass and bubbles) in scoriae of the four units of the tephra fall deposits. The crystal fraction $\phi$ of each phase was calculated on a vesicle-free basis:

$$
\phi=\frac{A_{x t a l}}{A_{r}}
$$

where $A_{x t a l}$ is the area of the crystal phase and $A_{r}$ is the reference area used for the image analysis of natural samples $\left(105 \mathrm{~mm}^{2}\right.$ per each sample). The sizes of crystal phases were also measured using ImageJ software. All crystal fraction data are provided in Table 1.

Crystal size distribution (CSD) analysis provides quantitative information on relationships between crystal population density and crystal length for a population of crystals. Calbuco scoriae were used to analyse plagioclase CSD in order to quantify the nucleation events occurred before the eruption and to estimate the magma residence time based on the relationship between plagioclase population density, crystal sizes, and experimentally determined plagioclase growth rates. Crystal dimensions and abundances of each size population were recovered through analysis of BSE images using ImageJ software. The relationship between crystal population density and crystal length for a population of crystals was then obtained using CSD Corrections 1.6 (Higgins 2000, 2002). The linear relation provides estimates of timescales of magmatic processes, as the slope of the correlation is equal to $-1 /($ growth rate $\times$ residence time) (Higgins 2000) 


\section{$2.3 X$-Ray Fluorescence $(X R F)$}

Bulk rock compositions of juvenile material were measured at the School of Earth and Environmental Sciences of the University of Manchester by X-ray fluorescence (XRF) spectrometry. The PAN analytical spectrometer, characterised by wavelength dispersive (WDXRF) systems, was used to analyse the bulk major and trace element compositions of the scoria clasts. This instrument uses a $\mathrm{Rh}$ anode $\mathrm{X}$-ray tube and is configured for geochemical analysis of rocks (Potts and Webb, 1992). The precision is better than $5 \%$ for all major elements and better than $10 \%$ for trace elements.

\subsection{Electron microprobe analysis (EMPA)}

Major element concentrations of minerals, plagioclase-hosted melt inclusions (MIs) and matrix glasses were analysed using a Cameca SX100 at Centro Nazionale di Ricerca of Firenze (Italy) and a JEOL JXA-8530F field emission electron microprobe at the Photon Science Institute, University of Manchester. For both instruments, the operating conditions were as follows: $15 \mathrm{kV}$ accelerating voltage, $10 \mathrm{nA}$ beam current, and beam diameter of 10 or $5 \mu \mathrm{m}$ (the latter for microlites). Sodium and potassium were measured first to minimise loss by volatilisation. Calibration standards were albite for $\mathrm{Na}$, periclase for $\mathrm{Mg}$, corundum for $\mathrm{Al}$, fayalite for $\mathrm{Fe}$, tephroite for $\mathrm{Mn}$, apatite for $\mathrm{P}$, sanidine for $\mathrm{K}$, wollastonite for $\mathrm{Ca}$ and $\mathrm{Si}$ and rutile for Ti. The uncertainty is between 1 to $5 \%$ for major elements and up to $10 \%$ for elements at concentration $<0.2 \mathrm{wt} \%$.

\subsection{Laser ablation ICP-MS}

Trace element concentrations in minerals (plagioclase, orthopyroxene, clinopyroxene), plagioclase-hosted MIs and matrix glasses were determined by Laser Ablation Inductively Coupled Plasma Mass Spectrometry (LA-ICP-MS) at the Department of Physics and Geology, 
University of Perugia (Italy). The instrumentation consisted of a Teledyne/Photon Machine G2 LA device equipped with a Two-Volume ANU HelEx 2 cell coupled with a Thermo Scientific $^{\mathrm{TM}}$ quadrupole-based iCAP Q ICP-MS. Analyses were performed using a circular laser beam with a diameter of $20 \mu \mathrm{m}$, frequency of $8 \mathrm{~Hz}$, and a laser density on the sample surface of $3.5 \mathrm{~J} / \mathrm{cm}^{2}$. The instrument was calibrated using the reference material NIST SRM610 , and ${ }^{29} \mathrm{Si}$ as an internal standard. The USGS reference material BCR2-G was analysed as an unknown in order to monitor precision and accuracy (Rocholl, 1998), which are better than $10 \%$ for all elements under these operating conditions (Petrelli et al., 2016).

The acquisition of measured transient signals allows the identification of melt inclusions in crystals (Longerich et al., 1998). Raw data were carefully screened for such inclusion signals and these were then manually removed.

\subsection{Raman spectroscopy}

Raman spectra were collected from exposed melt inclusions hosted in plagioclase, orthopyroxene and clinopyroxene phenocrysts, using a Thermo Scientific ${ }^{\mathrm{TM}} \mathrm{DXR}^{\mathrm{TM}} \mathrm{xi}$ Raman Imaging Microscope at the School of Earth Sciences, University of Bristol (UK). The spectrometer is equipped with a $532 \mathrm{~nm}$ doubled Nd:YVO4 DPSS, a 900 lines $\times \mathrm{mm}^{-1}$ grating, and a magnetic stage. Spectra were acquired between $100 \mathrm{~cm}^{-1}$ and $4000 \mathrm{~cm}^{-1}$ using a $100 \times$ objective, $25 \mu \mathrm{m}$ confocal pinhole, and $3 \mathrm{~mW}$ of laser power on the sample at a depth of $\sim 6$ $\mu \mathrm{m}$. The acquisition time was set to $20 \times 3 \mathrm{sec}$ in order to maximise the signal-to-noise ratio.

The acquired spectra were corrected for temperature and excitation line effects according to Long (1977). For the silicate region, a background subtraction was applied following the strategy of Di Genova et al. (2016), where a cubic spline was fit through two intervals devoid of peaks (100-250 and 1250-1500 $\mathrm{cm}^{-1}$, respectively). A cubic baseline between 2750-3100 and $3750-3900 \mathrm{~cm}^{-1}$ was applied to the water region. A set of standards of dacitic composition (HO 
series from Di Genova et al., 2017) was used to estimate the water content of the melt inclusions. This was calculated using the ratio between the band area of the water (HW) and silicate (LW) region (i.e. internal calibration). The root mean square error (RMSE) of the water content measured using the internal calibration is 0.15 wt.\% (Di Genova et al., 2017).

\section{Results}

\subsection{Tephra fall deposits}

The eruptive sequence is subdivided in four units: A, B, C, and D. The sequence starts with unit A (showing a reverse grading; Fig.1), which was deposited during the first phase of the eruption (Romero et al., 2016; Castruccio et al., 2016). Units B, C and D were deposited during the second phase of eruption (Castruccio et al., 2016). At site DF10 (Fig. 1) unit A consists of two types of lapilli-size scoriae; one is lowdensity, vesicular and light grey to light brown in colour (74 vol.\%), and the other is high density, poorly vesicular and grey to brown in colour (23 vol.\%). Lithics are also present (3 vol.\%). The sequence continues with units B and C of the second eruptive phase, which are normally graded and ungraded, respectively. Units B and C are composed of brown scoriae with sizes from coarse lapilli to bomb-sized. At site DF10 (Fig. 1) both units $\mathrm{B}$ and $\mathrm{C}$ consist of low-density, vesicular and light brown scoriae (60 vol.\%); high-density, poorly vesicular brown scoriae (37 vol.\%); and lithics (3 vol.\%). Finally, the uppermost unit D is ungraded and composed of high-density, poorly vesicular lapilli scoriae (71 vol.\%); low-density, vesicular lapilli scoriae (24 vol.\%); and lithics (4 vol.\%).

\subsection{Textures}

The mineral assemblage in the scoriae consists of plagioclase $(\mathrm{Pl})$, orthopyroxene $(\mathrm{Opx})$, clinopyroxene (Cpx), titanomagnetite (Ti-Mag) and olivine (Ol) (Figs. 1 and 2). Scoria clasts are characterised by isolated phenocrysts and glomeroporphyritic textures (Fig. 1). The 
groundmass is characterised by microlites of plagioclase, clinopyroxene, orthopyroxene and titanomagnetite, plus glass (Figs. 1 and 2). In general, phenocrysts have euhedral blocky and prismatic shapes (Fig. 1). Microlites are characterised by euhedral, hopper, swallowtail and skeletal morphologies with prismatic to acicular habits (Figs. 1 and 2).

The plagioclase crystal fraction $\phi_{\mathrm{Pl}}$ is constant throughout the four units of the tephra fall deposit: $\phi_{\mathrm{Pl}}$ ranges between 0.23 and 0.27 for phenocrysts, in particular, the crystal fraction of plagioclase cores is $\sim 0.10$, whereas $\phi$ of plagioclase overgrowth is $\sim 0.15$. The microlite crystal fraction ranges from 0.17 to 0.21 (Table 1), in which the crystal fraction of blocky microlites is $\leq \sim 0.10$ with respect to the analysed sample. Crystal size distribution (CSD) analysis shows 3 populations of plagioclase crystals (Fig. 3 and Supplementary Table 1). Plagioclase phenocrysts are characterised by a normally zoned core and an overgrowth rim with oscillatory zoning (Fig. 4) and their sizes range between $300 \mu \mathrm{m}$ and $1.5 \mathrm{~mm}$. Oscillatory zoning shows internal resorption and growth morphologies (Fig. 4), sieve textures (Fig. 4e) and patchy zoning textures (Fig. 4e, f). Plagioclase microlites vary from 1 to $250 \mu \mathrm{m}$ in size. Two textures can be distinguished in plagioclase microlites: those with sizes between 25 and $250 \mu \mathrm{m}$ have euhedral prismatic shapes with occasional oscillatory zoning (blocky microlites), while those with sizes $<15 \mu \mathrm{m}$ are elongated, acicular crystals with hopper and swallowtail shapes (skeletal microlites). The larger blocky plagioclase microlites have CSD slopes that range between 12.44 and -21.72 , while the smaller skeletal microlites have CSD slopes between -221.69 and 319.85 (Supplementary Table 1).

Pyroxene crystals (Opx and Cpx) are less abundant than plagioclase crystals and $\phi_{\mathrm{Px}}$ ranges from 0.07 to 0.14 ( $\phi_{\text {Px-phenocryst }}: 0.07-0.09, \phi_{\text {Px-microlite: }}<0.01-0.04$; Table 1$)$. Pyroxene phenocryst sizes range between 200 and $700 \mu \mathrm{m}$, whereas the dimensions of microlites are between $1 \mu \mathrm{m}$ and $<130 \mu \mathrm{m}$. 
Titanomagnetite phenocrysts are commonly found within glomerocrysts and their crystal fraction is constant at $\phi_{\mathrm{Ti}-\mathrm{Mgt}}=0.01$ through the four units of the tephra fall deposit (Table 1). Titanomagnetite phenocrysts are $\sim 120$ to $\sim 300 \mu \mathrm{m}$ in diameter, while microlites are $<100 \mu \mathrm{m}$. In the groundmass, $\phi_{\mathrm{Ti}-\mathrm{Mgt}}$ is $<<0.01$.

Olivine crystals are typically found in glomerocrysts or as inclusions in the cores of orthopyroxene phenocrysts. Olivine is an accessory phase and $\phi_{\mathrm{Ol}}$ is $<0.01$. Olivine crystals are characterised by anhedral habits, which indicate resorption and disequilibrium conditions.

Melt inclusions are hosted in plagioclase, orthopyroxene and clinopyroxene phenocrysts. Plagioclase-hosted MIs are characterised by spherical, oblate and polygonal shapes (Fig. 4e, f) and have diameters between 30 to $100 \mu \mathrm{m}$. Ortho- and clinoyroxene-hosted inclusions are much smaller, with diameters generally $<40 \mu \mathrm{m}$, and are often irregularly shaped.

\subsection{Bulk rock, MIs and glass compositions}

The bulk rock composition of the juvenile material is basaltic andesitic containing 55-56 wt.\% $\mathrm{SiO}_{2}$ (Fig. 5; Supplementary Table 2). There is no statistically significant compositional difference between the four units of the tephra fall deposit.

Melt inclusions (MIs) hosted in orthopyroxene and clinopyroxene phenocrysts were difficult to characterise chemically as their small sizes (smaller than those hosted in plagioclase) precluded microprobe analysis. MIs hosted in plagioclase phenocrysts, mostly entrapped in external layers (Fig. 4e, f), have compositions from andesitic to low-silica dacitic, with $\mathrm{SiO}_{2}$ between 58 and 62 wt.\% (Fig. 5; Supplementary Table 3). Only plagioclase-hosted MIs were chemically characterized, as their sizes allowed us to analyse by EPMA and LA-ICP-MS. Plagioclase-hosted MIs were corrected for post-entrapment crystallisation (PEC) following the method of Neave et al. (2017), incrementally adding equilibrium plagioclase back into the inclusions until their $\mathrm{MgO}-\mathrm{Al}_{2} \mathrm{O}_{3}$ systematics were consistent with a liquid line of descent 
connecting bulk rock and glass compositions. Trace elements were corrected using partition coefficients collated from the Geochemical Earth Reference Model database (https://earthref.org/GERM/); volatiles were assumed to be perfectly incompatible. The mean PEC correction applied was $13.8 \%$ (range $1-30 \%$ ).

The matrix glass ranges from andesite to dacite $\left(\mathrm{SiO}_{2}\right.$ between 61 and 65 wt.\%) (Fig. 5; Supplementary Table 3). The full range of matrix glass compositions is found within each unit of the tephra fall deposit. Harker-style diagrams show that $\mathrm{Al}_{2} \mathrm{O}_{3}, \mathrm{FeO}, \mathrm{MgO}$ and $\mathrm{CaO}$ decrease as $\mathrm{SiO}_{2}$ increases (Fig. 5a, b, c, d), highlighting a chemical evolution from bulk rock to residual melt, passing through the corrected $\mathrm{MI}$ compositions. The decrease in $\mathrm{FeO}$ and $\mathrm{MgO}$ (Fig. 5b, c) may be due to the crystallisation of orthopyroxene, clinopyroxene and oxides, while the variations in $\mathrm{CaO}$ content (Fig. 5d) are primarily controlled by plagioclase crystallisation. The observed variability in $\mathrm{Na}_{2} \mathrm{O}$ (Fig. 5e) could be a real magmatic feature partially controlled by plagioclase crystallisation, or could be due to slight $\mathrm{Na}_{2} \mathrm{O}$ loss during EPMA analysis. However, EPMA analyses were carefully performed in order to avoid $\mathrm{Na}_{2} \mathrm{O}$ loss. Our PEC correction has little effect on the $\mathrm{Na}_{2} \mathrm{O}$ content of the inclusions and does not decrease the variability in measured $\mathrm{Na}_{2} \mathrm{O}$ contents (Fig. 5e). Figure $5 f$ shows that $\mathrm{K}_{2} \mathrm{O}$ is enriched in the residual melt as it is incompatible in plagioclase, orthopyroxene and clinopyroxene. Trace element data also show an enrichment of incompatible elements (e.g., $\mathrm{Rb}, \mathrm{Y}, \mathrm{Nb}, \mathrm{Ba}$ and $\mathrm{La}$ ) in the matrix glass, consistent with residual melt differentiation obtained with the fractional crystallisation model (Neumann et al., 1954; Petrelli et al., 2005) (Fig. 6). Sr contents are more variable than other trace elements (Fig. 6b) because $\mathrm{Sr}$ is slightly compatible in plagioclase and the partitioning of Sr between plagioclase and melt is a function of the anorthite (An) content (Blundy and Wood, 1991; Aigner-Torres et al., 2007).

\subsection{Chemical composition of crystal phases}


Plagioclase phenocrysts typically exhibit a normally zoned core and an oscillatory zoned overgrowth rim (Fig. 4). Plagioclase cores are characterised by An contents between 78 and 93 mol.\% (Fig. 7a). The An content of the overgrowth rims varies from 58 to 77 mol.\% (Fig. 7a). The overgrowth rims, particularly the external rims in contact with the melt $\left(\mathrm{An}_{61-75}\right)$, have compositions similar to the microlites $\left(\mathrm{An}_{63-70}\right)$ (Fig. 7a). Therefore, the transition between the core and the oscillatory zoned overgrowth rim is characterized by an important decrease of An content, however, this transition is not associated with a significant variation of $\mathrm{FeO}$ and $\mathrm{MgO}$ (Fig. 8). Therefore, concentrations of $\mathrm{FeO}$ and $\mathrm{MgO}$ in plagioclase are approximately constant from the core to the overgrowth rim (through the oscillatory zoning).

Orthopyroxene phenocrysts are slightly compositionally heterogeneous with En content between 63 and 73 mol.\% ( $\mathrm{En}_{65-73}, \mathrm{Fs}_{24-32}, \mathrm{Wo}_{2-4}$; Fig. $\left.7 \mathrm{~b}\right)$. Clinopyroxene phenocrysts are uniformly augitic at $\mathrm{En}_{41-45}, \mathrm{Fs}_{10-15}, \mathrm{Wo}_{41-45}$ (Fig. 7b). Olivine crystals have compositions ranging from $\mathrm{Fo}_{72}$ to $\mathrm{Fo}_{66}$, and are normally zoned (Fig. 7c).

\section{$3.5 \mathrm{H}_{2} \mathrm{O}$ in $\mathrm{MIs}$}

Using Raman spectroscopy, we estimated the water contents of 109 MIs hosted in orthopyroxene (43), clinopyroxene (15), and plagioclase (51) phenocrysts (Fig. 9a). In the 43 Opx-hosted MIs from units A, B, C and D, the $\mathrm{H}_{2} \mathrm{O}$ contents range from 2.5 wt.\% to 5.8 wt.\% (Fig. 9a; Supplementary Table 4). In the $15 \mathrm{Cpx}$-hosted MIs, the $\mathrm{H}_{2} \mathrm{O}$ contents range from 2.5 wt.\% to 6 wt.\% (Fig. 9a). In the 51 Pl-hosted MIs, the $\mathrm{H}_{2} \mathrm{O}$ contents range from 3.6 wt.\% to 6.7 wt.\% (Fig. 9a). Figure 9 shows that the $\mathrm{H}_{2} \mathrm{O}$ contents are mostly constant in pyroxene-hosted MIs from units A, B and C. Pyroxene-hosted MIs from unit D have slightly lower measured $\mathrm{H}_{2} \mathrm{O}$ contents, but are not significantly different from the earlier three units within the uncertainty of the measurements. Plagioclase-hosted MIs are characterised by near-uniform $\mathrm{H}_{2} \mathrm{O}$ contents across all units of the tephra fall deposit (Fig. 9a). 
The range of measured $\mathrm{H}_{2} \mathrm{O}$ contents in our melt inclusions (Fig. 9a) could indicate that diffusive re-equilibration of $\mathrm{H}_{2} \mathrm{O}$ occurred between the MIs and their external environment (e.g. Massare et al., 2002). However, the plagioclase- and pyroxene-hosted inclusions are often associated with large bubbles, which could be indicative of heterogeneous trapping of fluid and melt. Numerical models suggest that the glass phase in heterogeneously trapped inclusions is less susceptible to post-entrapment modification of volatile contents (Steele-Macinnis et al., 2017); therefore we consider it reasonable to assume that the range of the highest measured $\mathrm{H}_{2} \mathrm{O}$ contents is between 5.5 and 6.5 wt.\% in plagioclase- and pyroxene-hosted MIs and is representative of the highest pre-eruptive melt water content (Fig. 9a).

\section{Discussion}

4.1 Pre-eruptive conditions and timescales of the Calbuco sub-Plinian eruption

\subsubsection{Pre-eruptive temperatures and pressures}

Pre-eruptive temperature $(\mathrm{T})$ conditions of the Calbuco magma reservoir have been calculated using the mineral-melt thermometers of Putirka (2008) for orthopyroxene, clinopyroxene and plagioclase. The plagioclase-liquid hygrometer-thermometer of Waters and Lange (2015) was used to better constrain the range of temperatures under which plagioclase cores was able to grow. Detailed results from thermometric calculations and tests for mineralmelt equilibrium are presented in Supplementary Table 5.

All measured clinopyroxene compositions were tested for equilibrium against the mean bulk rock, plagioclase-hosted MIs (PEC-corrected MIs) and mean matrix glass compositions from units A-D. We evaluated equilibrium on the criterion $K_{D}=0.28 \pm 0.08$ (Putirka, 2008). All the clinopyroxene crystals analysed in this study passed the equilibrium criterion with the less evolved MI compositions with $0.25<\mathrm{K}_{\mathrm{D}}<0.26$. Clinopyroxene crystallisation temperatures were calculated considering 5.5 and 6.5 wt. $\% \mathrm{H}_{2} \mathrm{O}$ as the highest pre-eruptive melt water content 
(Fig. 9a). The clinopyroxene-MI liquid equilibration temperatures range between 961 and 988 ${ }^{\circ} \mathrm{C}$ (Eqn. 33; Putirka, 2008) (Fig. 10a).

All analysed orthopyroxene compositions were tested for equilibrium against the mean bulk rock, plagioclase-hosted MIs (PEC-corrected MIs) and mean matrix glass compositions. All the orthopyroxene crystals analysed passed the equilibrium criterion $K_{D}=0.29 \pm 0.06$ (Putirka, 2008) with the less evolved MI compositions. Orthopyroxene crystallisation temperatures were then calculated assuming magmatic $\mathrm{H}_{2} \mathrm{O}$ contents of 5.5 and 6.5 wt.\% (Fig. 9a). Calculated orthopyroxene-liquid equilibration temperatures range between 970 and $987{ }^{\circ} \mathrm{C}$ (Fig. 10a). These temperatures are similar to those obtained for clinopyroxene, suggesting that ortho- and clinopyroxene were grown under the same magmatic conditions (Fig. 10a).

Further evidence to constrain pre-eruptive conditions was obtained using plagioclase-liquid thermometry. Plagioclase compositions were tested for equilibrium with the PEC-corrected MI and the mean matrix glass compositions and only equilibrium pairs with $\mathrm{K}_{\mathrm{D}}(\mathrm{An}-\mathrm{Ab})^{\mathrm{Pl}-\mathrm{liq}}=$ $0.10 \pm 0.05$ at $\mathrm{T}<1050{ }^{\circ} \mathrm{C}$ were considered. Plagioclase phenocryst cores with $\mathrm{An}_{78-93}$ were calculated to be in equilibrium with the less evolved MI compositions (with 5.5 and 6.5 wt.\% $\mathrm{H}_{2} \mathrm{O}$ ) at temperature between 927 and $963{ }^{\circ} \mathrm{C}$ (Fig. 10a). Plagioclase blocky microlites (with sizes from 25 to $250 \mu \mathrm{m} ; \mathrm{An}_{63-70}$ ) are also in equilibrium with the melt inclusion and matrix glass compositions at temperatures between 900 and $926^{\circ} \mathrm{C}$ (Fig. 10a).

The plagioclase-liquid hygrometer-thermometer (Waters and Lange, 2015) recovers and confirms that the plagioclase phenocryst cores $\left(\mathrm{An}_{84-93}\right)$ are in equilibrium with the less evolved MI compositions at temperatures between 900 and $940{ }^{\circ} \mathrm{C}$ (Fig. 10a) and $\mathrm{H}_{2} \mathrm{O}$ between 5.4 and 6.1 wt. \% (this amount is consistent with the maximum amount of $\mathrm{H}_{2} \mathrm{O}$ measured in MIs).

The uncertainty of the Putirka (2008) ortho- and clinopyroxene-liquid, and plagioclaseliquid thermometers is $\pm 48{ }^{\circ} \mathrm{C}$, the plagioclase-liquid hygrometer-thermometer (Waters and 
Lange, 2015) is $\pm 12{ }^{\circ} \mathrm{C}$. This implies that the pre-eruptive temperature of the phenocrysts overlap within this degree of error.

We note that plagioclase overgrowth rim compositions (characterised by oscillatory zoning) may result from disequilibrium crystallisation due to high undercooling, magma convection and thermal mixing, therefore temperatures were not calculated from these compositions.

Pre-eruptive conditions of the Calbuco magma reservoir also have been calculated using Rhyolite-MELTS software (version 1.2) (Ghiorso et al. 2012; Ghiorso and Gualda, 2015). The range of temperatures obtained from thermometers was used together with the highest amount of $\mathrm{H}_{2} \mathrm{O}$ measured in MIs (5.5 to 6.5 wt.\% of $\mathrm{H}_{2} \mathrm{O}$ ). The bulk rock composition was used for the simulations. In accordance with the $\mathrm{H}_{2} \mathrm{O}$ solubility in basaltic andesitic melts predicted by Moore et al. (1998), the water-saturated conditions of this basaltic andesite magma with 5.5 and 6.5 wt.\% of $\mathrm{H}_{2} \mathrm{O}$ would be reached at pressures between 230 and $320 \mathrm{MPa}$ (Fig. 9b). Our simulations investigated a wider range of pressures in order to constrain the possible preeruptive $\mathrm{P}$ and $\mathrm{T}$ conditions where oxide, orthopyroxene, clinopyroxene and plagioclase phenocrysts were able to form (Supplementary Table 6). Particularly, pre-eruptive pressures and temperatures were constrained by replicating the same mineral assemblage and crystal volume fraction of natural samples (Supplementary Table 6). Rhyolite-MELTS simulations show that the observed crystal fraction of oxide, orthopyroxene, clinopyroxene and plagioclase cores were formed at 260-320 MPa ( 10-12 km, in excellent agreement with pressures calculated from dissolved $\mathrm{H}_{2} \mathrm{O}$ contents) and temperatures between 940 and $950{ }^{\circ} \mathrm{C}$ (Supplementary Table 6). Considering the total phenocryst volume fraction, therefore, taking into account the plagioclase overgrowth rims and the blocky microlites, the pre-eruptive pressures predicted from Rhyolite-MELTS range between 230 and $320 \mathrm{MPa}$, whereas temperature ranges between 900 and $950{ }^{\circ} \mathrm{C}$ (Figure 10b; Supplementary Table 6). This means that the Calbuco magma was probably water-saturated before the eruption (Fig. 9b). 
Furthermore, the pre-eruptive temperatures obtained with Rhyolite-MELTS simulations indicate an overall cooling of the magma reservoir before the eruption.

The pre-eruptive temperatures of the magma obtained in this study (900 to $950{ }^{\circ} \mathrm{C}$ ) are comparable with those estimated by Morgado et al. (2019) (910 to $\left.970{ }^{\circ} \mathrm{C}\right)$. The pre-eruptive pressures obtained here (230 to $320 \mathrm{MPa}$ ) are higher than the 140 to $260 \mathrm{MPa}$ estimated by Morgado et al. (2019). The pressures estimated by Morgado et al. (2019) are inconsistent with the $\mathrm{H}_{2} \mathrm{O}$ content of MIs (5.5 to 6.5 wt.\%), as volatile solubility models would predict lower melt $\mathrm{H}_{2} \mathrm{O}$ concentrations at these pressures. Therefore, only the highest pressures estimated by Morgado et al. (2019) are compatible with our measured $\mathrm{H}_{2} \mathrm{O}$ contents and with pressuredependent $\mathrm{H}_{2} \mathrm{O}$ solubility models for basaltic andesitic and andesitic melt compositions (Moore et al., 1998).

\subsubsection{Closed vs open system}

Scoriae textures and plagioclase CSDs show that at least three events of crystal nucleation and growth occurred, producing in sequence: (1) phenocrysts (titanomagnetite, orthopyroxene, clinopyroxene and plagioclase cores; Figs 1 and 3); (2) overgrowth rims around plagioclase, and blocky microlites (plagioclase, clinopyroxene and orthopyroxene) with sizes from $\sim 25$ to $\sim 250 \mu \mathrm{m}$ (Figs 1, 2 and 3); and (3) skeletal microlites <15 $\mu \mathrm{m}$ (Figs 2 and 3). The distinction between the first and second events is based on the different chemical compositions of the plagioclase cores and the overgrowth rims and blocky microlites. On the other hand, the compositional similarity between overgrowth rims $\left(\mathrm{An}_{58-77}\right)$ and blocky microlites $\left(\mathrm{An}_{63-70}\right)$ suggests that they crystallised together under the same magmatic conditions (Fig. 10b).

The normal zoning of the plagioclase cores is in agreement with an initial slow cooling of the magma in a closed system; however, water-saturated decompression also induces the crystallisation of more sodic compositions (Blundy and Cashman, 2001), causing a progressive 
decrease of An content within the crystallising mineral (plagioclase core). The oscillatory zoning in plagioclase crystals shows resorption morphologies (Fig. 4) and sieve and patchy zoning textures (Fig. 4e, f), which may relate to different processes:

(i) open-system processes, such as mafic magma recharge and chemical mixing (Ginibre et al., 2002; Ruprecht and Wörner, 2007; Ginibre and Wörner, 2007; Ginibre et al., 2007);

(ii) closed-system processes (closed-system for magma but not volatiles), such as decompression, heat transfer, and thermal mixing in response to a thermal perturbation, associated with a magma chamber overturn (Ginibre et al., 2002; Ruprecht and Wörner, 2007; Ginibre and Wörner, 2007; Ginibre et al., 2007).

It is important to note that our chemical data show $\mathrm{FeO}$ and $\mathrm{MgO}$ remain constant whilst $\mathrm{An}$ content decreases from plagioclase cores to oscillatory zoned overgrowth rims (Fig. 8). The observation of resorption and growth morphologies (Fig. 4c), sieve textures and patchy zoning textures (Fig. 4e, f) in plagioclase crystals, combined with constant $\mathrm{FeO}$ and $\mathrm{MgO}$ contents suggest that the oscillatory zoning was not caused by magma recharge and consequent magma mixing, but rather represents closed-system differentiation due to thermal mixing during magma convection (thermal gradients within the chamber) or decompression events (Ginibre et al., 2002; Ruprecht and Wörner, 2007; Ginibre and Wörner, 2007; Ginibre et al., 2007). We highlight that the evidence from zoned crystals supports a closed system before the 2015 eruption. Furthermore, no mafic enclaves and macroscopic magma heterogeneities are observed in the erupted products, indicating that magma intrusion immediately before the eruption was unlikely.

The crystallisation sequence is confirmed by whole-rock, melt inclusion and glass major element compositional trends, which are consistent with melt differentiation without magma mixing. Mass balance calculations computed using Petrograph software (Petrelli et al., 2005) show that the Calbuco bulk composition (basaltic andesite) can evolve to dacite through $\sim 53 \%$ 
crystallisation of plagioclase, orthopyroxene, clinopyroxene and titanomagnetite (Supplementary Table 7). Trace element differentiation trends have also been modelled in agreement with Neuman et al. (1954) using Petrograph. The melt fraction was varied from 0.47 to 1 in agreement with textural analysis. Figure 6 shows that the observed trace element variations in the Calbuco erupted products can be successfully described by closed-system melt differentiation.

\subsubsection{Multidisciplinary constraints}

Assuming a lithospheric pressure gradient and crustal density of $2.7 \mathrm{~g} / \mathrm{cm}^{3}$, our calculated pressures of 230-320 $\mathrm{MPa}$ correspond to a magma reservoir located 8.5 to $12 \mathrm{~km}$ beneath Calbuco volcano. Although this is a wide depth range, the shallower part of this range is close to the recorded depths of pre-eruptive seismicity. Indeed, between 1 January and 21 April 2015, 147 volcano-tectonic (VT) earthquakes were recorded and located at depths of $6.5-8 \mathrm{~km}$ beneath Calbuco (SERNAGEOMIN, 2015; Valderrama et al., 2015) (Figs 10a and 11; Supplementary Table 8). This activity marked a very small increase in energy when compared to the Calbuco seismic baseline. The low magnitude and frequency of earthquakes, and the absence of other coeval geophysical anomalies was not considered to be indicative of renewed unrest (Valderrama et al., 2015). On 22 April at 18:11 GMT (15:11 local time), 3 hours before the eruption, a seismic swarm consisting of $\sim 140$ VT events was recorded (SERNAGEOMIN, 2015; Valderrama et al., 2015) at depths of $\sim 7 \mathrm{~km}$. The hypocentral depth of the pre-eruptive VT swarms is likely to indicate the rooftop of the magma chamber before the eruption (Figs 10a and 11). A magma reservoir located 8 to $11 \mathrm{~km}$ below the summit has also been inferred by modelling the co-eruptive subsidence recorded by Interferometric Synthetic Aperture Radar (InSAR) during the 22-23 April 2015 eruption (Delgado et al., 2017). Our pressures predicted by Rhyolite-MELTS simulations are consistent with these independent observations. 


\subsubsection{Timescales of crystal growth}

Plagioclase residence times were estimated by combining CSD slopes and experimental growth rates, as residence time is equal to $-1 /($ growth rate $\times$ CSD slope $)$. We used the maximum $\left(1.32 \times 10^{-2} \mathrm{~mm} / \mathrm{h}\right)$ and the minimum $\left(1.50 \times 10^{-3} \mathrm{~mm} / \mathrm{h}\right)$ plagioclase growth rates estimated by Shea and Hammer (2013) for basaltic andesitic melts. We also assume a slow growth rate for plagioclase of $3.96 \times 10^{-5} \mathrm{~mm} / \mathrm{h}$ from a series of experimental growth rates, obtained from basaltic melts (Agostini et al., 2013; Arzilli et al., 2015), in order to take into account the slower crystallisation kinetics of plagioclase phenocrysts and zoned blocky microlites. Calculated residence times for plagioclase phenocrysts range from several days to $\sim 8$ months (Supplementary Table 1 ). For blocky microlites (25 to $250 \mu \mathrm{m}$ ) the residence time ranges between a few hours to $\sim 2$ days (estimated with the faster growth rates), consistent with crystallisation experiments performed by Shea and Hammer (2013) in which plagioclase microlites were able to form over 12 to 48 hours. The maximum residence time estimated for blocky microlites is 2 months (Supplementary Table 1). Therefore, these timescales suggest that the population of blocky microlites $(25-250 \mu \mathrm{m})$ may represent a final, crystallisation event before the onset of the eruption, and therefore before syneruptive decompression could begin. Furthermore, we suggest that skeletal microlites of plagioclase and pyroxene with size $<15 \mu \mathrm{m}$ (Fig. 3) were grown in syn-eruptive conditions during rapid magma ascent, i.e. during decompression-induced crystallisation (Blundy and Cashman, 2001), as their residence time ranges between a few minutes to $\sim 3$ hours. This is consistent with the time passed between the last seismic swarm and the eruption. This crystallisation event produced a further evolution of the residual melt towards dacitic compositions (measured in the matrix glass; Fig. 5). 
Since all the samples analysed in the present study show similar textural, chemical and mineralogical features, it is possible to infer that the magma erupted during the first and second phases of the sub-Plinian eruption experienced the same pre-eruptive conditions.

\subsection{Triggering of the Calbuco sub-Plinian eruption}

The Calbuco sub-Plinian eruption (22-23 April 2015) occurred with just three hours warning from geophysical data. This poses a clear challenge for volcanologists and risk managers: what are the conditions under which a volcanic system may produce a sudden unexpected violent eruption? In the Calbuco 2015 case, the pre-eruptive conditions and the timescales of the processes, constrained using petrological, geochemical and seismic data, allow us to compare and contrast three different triggering mechanisms:

a) Second boiling induced by crystallisation prior to eruption due to the thermal mixing and convection within the magma chamber, i.e. an internal triggering mechanism in a closed system;

b) Gradual, slow decompression of the system and outgassing (e.g. Scandone, 1996; Ruprecht and Wörner, 2007; Ginibre and Wörner, 2007; Shea et al., 2009), which could have begun at least several hours/days before the sub-Plinian eruption, i.e. open system for volatiles but not magma;

c) Injection of hot magma into the magma chamber (as suggested by Morgado et al., 2019) and magma mixing, which may be considered an archetype of the external triggering mechanism for explosive eruption, i.e. open system for volatiles and magma.

\subsubsection{Second boiling induced by protracted crystallisation}

The $\mathrm{An}, \mathrm{FeO}$ and $\mathrm{MgO}$ profiles of plagioclase crystals (Fig. 8) indicate that the oscillatory zoning may have been produced by protracted resorption-regrowth events, caused by thermal 
mixing due to magma convection in a closed system (in agreement with Ginibre et al., 2002; Ruprecht and Wörner, 2007; Ginibre and Wörner, 2007; Ginibre et al., 2007). Rhyolite-MELTS simulations show that $0.10<\phi<0.15$ of high-anorthite plagioclase $\left(\mathrm{An}_{80-76}\right)$ can be formed at 930-950 ${ }^{\circ} \mathrm{C}$ and 250-320 MPa (Fig.10b; Supplementary Table 6) from the basaltic andesitic liquid (Supplementary Table 2). This may represent the initial conditions of the system that induced the crystallization of plagioclase cores, as $\phi$ and the An content are comparable to those analysed in the natural samples (Supplementary Table 3 and Supplementary Table 6). RhyoliteMELTS simulations show that a further $0.10<\phi<0.25$ of low-anorthite plagioclase $\left(\mathrm{An}_{70-57}\right)$ can be formed, in addition to the plagioclase core crystal content, at temperatures between 900 and $930{ }^{\circ} \mathrm{C}$ (Fig. 10b). Temperatures between 900 and $930{ }^{\circ} \mathrm{C}$ may represent the conditions where plagioclase oscillatory zoning and blocky microlites $(25-250 \mu \mathrm{m})$ formed, as $\phi$ and the An content are similar to those observed in the natural samples (Table 1 and Supplementary Table 3). Therefore, the oscillatory zoning observed within the plagioclase crystals may be the result of thermal mixing and magma convection driven by a thermal gradient of $\sim 30{ }^{\circ} \mathrm{C}$ within the chamber. The protracted crystallisation of phenocrysts and blocky microlites $(25-250 \mu \mathrm{m})$ may have induced second boiling (Blake, 1984; Tait et al., 1989; Fowler and Spera, 2008, 2010; Degruyter and Huber, 2014; Stock et al., 2016). In this scenario, the thermal convection of the magma may have favoured the formation of plagioclase oscillatory zoning, resorption morphologies (Fig. 4) and sieve and patchy zoning textures (Fig. 4e, f). A gradual cooling of the overall magmatic system and an increase in the total crystal content may have increased magma viscosity sufficiently to slow convection. We highlight that viscosity can increase by $\sim 4$ orders of magnitude (calculated using models of Giordano et al., 2008 and Vona et al., 2011) during an increase in crystal volume fraction from 15 to 45 vol\% (considering all the crystal phases at pre-eruptive conditions). Following this stage, further crystallisation and pressurisation from second boiling led to the eruption. The seismic activity produced shortly 
before eruption is likely to represent the pressure build-up prior to rapid magma ascent in the conduit. In the case of Calbuco, this interpretation is in agreement with the short-lived precursory seismic activity that occurred on 22 April, only $\sim 3$ hours before the eruption, at depths of $6.5-8 \mathrm{~km}$ (SERNAGEOMIN, 2015; Valderrama et al., 2015; Fig. 11). Periodic seismic swarms at near-constant depths beneath a volcano may indicate cooling and solidification of a stationary magma (Chouet, 1979). Furthermore, no significant pre-eruptive deformation was detected up to one day before the eruption from the tiltmeter and InSAR interferograms (Valderrama et al., 2015; Delgado et al., 2017). We highlight that the presence of abundant exsolved volatiles in the closed-system magma chamber would increase magma compressibility, attenuating deformation signals associated with pressure increase (Johnson et al., 2000; Delgado et al., 2017).

The original basaltic andesitic magma may have been evolved to a state in which eruption was triggered, without the need for an external triggering mechanism. Volatile exsolution is a key internal trigger for eruption-inducing over-pressurisation (Blake, 1984; Tait et al., 1989; Fowler and Spera, 2008, 2010; Degruyter and Huber, 2014; Tramontano et al., 2017). We note that Delgado et al. (2017) consider volatile exsolution in a closed system as a much more likely trigger mechanism for the Calbuco eruption than dike intrusion, based on the incongruence displayed by synthetic models, which account for a dipping dike to predict co-eruptive interferograms. This is also confirmed by the satellite imagery model developed by Pardini et al. (2018), which shows that magmatic volatiles were already exsolved before the onset of the Calbuco eruption.

To investigate the potential overpressure generated by second boiling, we performed a mass balance calculation (following the model developed by Tait et al., 1989) on a magmatic body with fixed volume. For this calculation, we assumed isothermal conditions and a closed magmatic system, i.e. no mass is exchanged with the surrounding rocks. We considered a 
magmatic body at $\sim 10 \mathrm{~km}(270 \mathrm{MPa})$, with a temperature of $950{ }^{\circ} \mathrm{C}$, containing 6.0 wt. $\%$ magmatic $\mathrm{H}_{2} \mathrm{O}$. The system is then forced to crystallise, causing a decrease in the mass of the melt in the magmatic body and a concentration of dissolved volatiles in the melt phase. This, in turn, increases the saturation pressure of the dissolved volatiles and, as soon as the saturation pressure exceeds the pressure of the reservoir, volatiles start to exsolve and pressurise the system. From the mass balance calculation we found that, once the magma reservoir is pressurised by exsolved volatiles, for each additional $1 \%$ of crystallisation there is a $2 \mathrm{MPa}$ increase in pressure. The overpressure at which failure occurs depends on the tensile strength of the surrounding rocks, but typically ranges from a few MPa to 10-20 MPa (Tait et al., 1989). Therefore, crystallisation of 10 vol. $\%$ is sufficient to over-pressurise the system and trigger eruption. This also signifies that crystallisation and the resulting second boiling could theoretically lead a "silent" magma stored in the crust beneath the volcano towards conditions favourable for the triggering of a large explosive eruption on timescales of hours to days.

While this mechanism for eruption triggering has been proposed by several authors (Stock et al., 2016), this is, to our knowledge, the first occurrence where an internal triggering process may have been recognised in a sub-Plinian eruption at the Earth's surface. Recent eruptions from several continental margin and island arc volcanoes have been characterised by short-term (i.e. hours) precursory seismic activity, including the sub-Plinian eruptions of Redoubt 1989 (Alaska; Nye et al., 1994), Galunggung 1982 (Java; Bluth et al., 1994), Reventador 2002 (Ecuador; Hall et al., 2004), Cordón Caulle 2011-2012 (Chile; Castro et al., 2013) and the Plinian eruption of Chaitén 2008 (Chile; Castro et al., 2009; Pallister et al., 2013). We therefore highlight that the internal triggering mechanism proposed for the 2015 Calbuco sub-Plinian eruption may be a common short-onset triggering mechanism for Plinian-type eruptions in continental and island arc volcanotectonic settings. Further studies should be performed in order to consider internal triggering mechanisms as potential causes for Plinian events. 


\subsubsection{Slow decompression}

A second hypothesis of a possible triggering mechanism is the slow decompression of the magma (Shea et al., 2009) before the explosive eruption. This mechanism is supported by experimental evidence but not from geophysical observations, as a pre-eruptive decompression in the days prior to eruption would have produced much more significant precursory signals (Scandone 1998; Francis et al. 1993). Focusing first on the supporting evidence we highlight that the mineral assemblage in the scoriae is more in agreement with the results obtained by decompression experiments performed by Shea and Hammer (2013) than those obtained from cooling experiments. Particularly, the absence of amphibole in the microlite assemblage may be related to decompression: in fact, amphibole forms more readily during cooling and tends to destabilize during decompression (Rutherford and Hill, 1993; Shea and Hammer, 2013). Furthermore, resorption-regrowth morphologies (Fig. 4c), and sieve and patchy zoning textures (Fig. 4e, f) in plagioclase phenocrysts, associated with significant An variations and constant $\mathrm{FeO}$ and $\mathrm{MgO}$ contents (Fig. 8), may suggest several decompression events and magma degassing should have occurred before the eruption (in agreement with Ginibre et al., 2002; Ruprecht and Wörner, 2007; Ginibre and Wörner, 2007; Ginibre et al., 2007). Our CSD and residence time analysis (Supplementary Table 1), in agreement with the experiments of Shea and Hammer (2013), shows that blocky microlites (25 to $250 \mu \mathrm{m}$ ) may be formed in a few hours/days. However, this would require a slower decompression than can be provided by the eruption itself. Furthermore, there is no evidence for slow magma ascent and degassing, with associated seismic activity and deformation prior to the eruption (Delgado et al., 2017).

\subsubsection{Injection of fresh magma into the magma chamber and magma mixing}


Injection of fresh magma into the magma chamber may be included amongst the possible triggering mechanisms of the Calbuco eruption. Morgado et al. (2019) suggested that localised heating, consistent with an injection of hot magma, could have triggered the 2015 Calbuco eruption. Data reported by Morgado et al. (2019) show that the injection of hot magma increased the temperature of only a small portion of the base of the magma reservoir by 70-200 ${ }^{\circ} \mathrm{C}$ (reaching up to $1070{ }^{\circ} \mathrm{C}$ ), whilst the remaining magma was not thermally affected. This conclusion is based on Fe-Ti oxide thermometry obtained from just one sample extracted from a pyroclastic density current deposit (Morgado et al., 2019). If a sudden injection of fresh magma into an evolved magma reservoir was the trigger of the eruption, textures of the samples in the overall eruption deposit might be expected to record evidence of magma mixing and mingling. However, the textural, chemical and mineralogical features of the scoriae show no clear evidence of mixing or mingling; mafic enclaves are absent; and no evidence such as compositional layering (Cioni et al., 1995) has been found in the volcanic deposits. Therefore, if injection of mafic magma occurred, efficient magma mixing is required to homogenize the magma composition. Injection of mafic magma may have occurred months/years before the eruption, but we do not see any evidence (e.g. mingling textures) of a sudden magma recharge before the eruption. Indeed, the significant $\mathrm{An}$ variations and the constant $\mathrm{FeO}$ and $\mathrm{MgO}$ contents across plagioclase oscillatory zones (Fig. 8) are not likely to have formed through compositional mixing, but rather they result from thermal mixing combined with an overall cooling of the system and/or decompression (Ginibre et al., 2002; Ruprecht and Wörner, 2007; Ginibre and Wörner, 2007; Ginibre et al., 2007).

\section{Conclusion and implications}

Prior to the 2015 sub-Plinian eruption of Calbuco, a basaltic andesite magma was stored at depths between 8 and $12 \mathrm{~km}$ (i.e. 230-320 MPa) beneath the volcano. We estimate that the 
initial temperature of the magma was between 900 and $950{ }^{\circ} \mathrm{C}$ and that crystallisation occurred under $\mathrm{H}_{2} \mathrm{O}$-saturated conditions (5.5-6.5 wt.\% $\left.\mathrm{H}_{2} \mathrm{O}\right)$. Crystallisation occurred under these conditions, producing phenocrysts of titanomagnetite, orthopyroxene, clinopyroxene and plagioclase cores $\left(\mathrm{An}_{78-93}\right)$. Plagioclase overgrowth rims $\left(\mathrm{An}_{58-77}\right)$ and blocky microlites (from 25 to $250 \mu \mathrm{m}$ ) grew during a second crystallisation event, which was caused by thermal mixing and magma convection within the chamber. A lack of geophysical signals precludes a slow decompression explanation for the blocky microlites. The rapid onset of a sub-Plinian eruption occurred with no evidence of magma intrusion, magma mixing and precursory deformation, and was, instead, caused by protracted crystallisation and second boiling over-pressurisation.

Such a triggering mechanism explains how violent sub-Plinian eruptions may occur with very little warning from geophysical monitoring. Ephemeral geophysical and seismic signals followed by unexpected violent eruptions should be more systematically studied in order to carefully evaluate the risks posed by apparently peaceful volcanoes.

\section{Acknowledgements}

We gratefully acknowledge funding support from the RCUK NERC DisEqm project (NE/N018575/1). The research leading to these results has received funding from the European Research Council under the European Union's Seventh Framework Programme (FP/20072013) / ERC Grant Agreement n. 279802 and from ERC Consolidator Grant 612776CHRONOS. We thank Paul Lythgoe and Alastair Bewsher for their assistance with X-ray fluorescence analysis. We thank T. Milian for support during the writing of the manuscript. We 
warmly thank Roger Smith for providing the photograph of the 2015 Calbuco eruption in Supplementary Figure 1. Finally, we thank the associate Editor, one anonymous reviewer and R.A. Corsaro for their thoughtful reviews that improved the paper. 


\section{References}

Agostini, C., Fortunati, A., Arzilli, F., Landi, P. and Carroll, M.R., 2013. Kinetics of crystal evolution as a probe to magmatism at Stromboli (Aeolian Archipelago, Italy). Geochimica et Cosmochimica Acta 110, 135-151.

Aigner-Torres, M., Blundy, J., Ulmer, P., Pettke, T., 2007. Laser ablation ICPMS study of trace element partitioning between plagioclase and basaltic melts: an experimental approach. Contributions to Mineralogy and Petrology 156, 647-667.

Aiuppa, A., Burton, M., Caltabiano, T., Giudice, G., Guerrieri, S., Liuzzo, M., Murè, F. and Salerno, G., 2010. Unusually large magmatic $\mathrm{CO}_{2}$ gas emissions prior to abasaltic paroxysm. Geophysical Research Letter 37, L17303.

Arzilli, F., Agostini, C., Landi, P., Fortunati, A., Mancini, L., Carroll, M.R., 2015. Plagioclase nucleation and growth kinetics in a hydrous basaltic melt by decompression experiments. Contribution to Mineralogy and Petrology 170, 55.

Biggs, J., Ebmeier, S.K., Aspinall, W.P., Lu, Z., Pritchard, M.E., Sparks, R.S.J., Mather, T.A., 2014. Global link between deformation and volcanic eruption quantified by satellite imagery. Nature communications 5, 3471 .

Blake, S., 1981. Volcanism and the dynamics of open magma chambers. Nature 289, 783-785.

Blake, S., 1984. Volatile oversaturation during the evolution of silicic magma cham- bers as an eruption trigger. Journal of Geophysical Research 89, 8237-8244.

Blundy, J., Cashman, K., 2001. Ascent-driven crystallisation of dacite magmas at Mount St Helens, 1980-1986. Contributions to Mineralogy and Petrology 140, 631-650.

Blundy, J.D., Wood, B.J., 1991. Crystal-chemical controls on the partitioning of $\mathrm{Sr}$ and $\mathrm{Ba}$ between plagioclase feldspar, silicate melts, and hydrothermal solutions. Geochimica et Cosmochimica Acta 55, 193-209. 
Blundy, J.D., Wood, B.J., 2003. Partitioning of trace elements between crystals and melt. Earth Planetary Science Letters 210, 383-397.

Bluth, G.J.S., Casadevall, T.J., Schnetzler, C.C., Doiron, S.D., Walter, L.S., Krueger, A.J., Badruddin, M., 1994. Evaluation of sulfur dioxide emissions from explosive volcanism: the 1982-1983 eruptions of Galunggung, Java, Indonesia. Journal of Volcanology and Geothermal Research 63, 243-256.

Caricchi, L., Annen, C., Blundy, J., Simpson, G., Pinel, V., 2014. Frequency and magnitude of volcanic eruptions controlled by magma injection and buoyancy. Nature Geoscience 7, 126130.

Cassidy, M., Castro, J.M., Helo, C., Troll, V.R., Deegan, F.M., Muir, D., Neave, D.A., Mueller, S.P., 2016. Volatile dilution during magma injections and implications for volcano explosivity. Geology 44, 1027-1030.

Castro, J.M., Dingwell, D.B., 2009. Rapid ascent of rhyolitic magma at Chaitén volcano, Chile. Nature 461, 780.

Castro, J.M., Schipper, C.I., Mueller, S.P., Militzer, A.S., Amigo, A., Parejas, C.S., Jacob, D., 2013. Storage and eruption of near-liquidus rhyolite magma at Cordón Caulle, Chile. Bulletin of Volcanology 75, 702.

Castruccio, A., Clavero, J., Segura, A., Samaniego, P., Roche, O., Le Pennec, J.L., Droguett, B., 2016. Eruptive parameters and dynamics of the April 2015 sub-Plinian eruptions of Calbuco volcano (southern Chile). Bulletin of Volcanology 78, 62.

Chouet, B.A., 1996. Long-period volcano seismicity: its source and use in eruption forecasting. Nature 380, 309-316.

Chouet, B.A., Page, R.A., Stephens, C.D., Lahr, J.C., Power, J.A., 1994. Precursory swarms of long-period events at Redoubt Volcano (1989-1990), Alaska: their origin and use as a forecasting tool. Journal of Volcanology and Geothermal Research 62, 95-135. 
Cioni, R., Civetta, L., Marianelli, P., Metrich, N., Santacroce, R., Sbrana, A. 1995. Compositional layering and syn-eruptive mixing of a periodically refilled shallow magma chamber: the AD 79 Plinian eruption of Vesuvius. Journal of Petrology 36, 739-776.

Delgado, F., Pritchard, M.E., Ebmeier, S., González, P., Lara, L., 2017. Recent unrest (2002-2015) imaged by space geodesy at the highest risk Chilean volcanoes: Villarrica, Llaima, and Calbuco (Southern Andes). Journal of Volcanology and Geothermal Research 344, 270-288.

Degruyter, W., Huber, C., 2014. A model for eruption frequency of upper crustal silicic magma chambers. Earth and Planetary Science Letters 403, 117-130.

de Silva, S., Salas, G., Schubring, S., 2008. Triggering explosive eruption-The case for silicic magma recharge at Huaynaputina, southern Peru. Geology 36, 387-390.

Di Genova, D., Kolzenburg, S., Vona, A., Chevrel, M.O., Hess, K.U., Neuville, D.R., Ertelingrisch, W., Romano, C., Dingwell, D.B., 2016. Raman spectra of Martian glass analogues: A tool to approximate their chemical composition. Journal of Geophysical Research: Planets 121, 740-752.

Di Genova, D., Sicola, S., Romano, C., Vona, A., Fanara, S., Spina, L., 2017. Effect of iron and nanolites on Raman spectra of volcanic glasses: reassessment of existing strategies to estimate the water content. Chemical Geology, 475, 76-86.

Dunn, T., Sen, C., 1994. Mineral/matrix partition coefficients for orthopyroxene, plagioclase, and olivine in basaltic to andesitic systems: a combined analytical and experimental study. Geochimica et Cosmochimica Acta, 58, 717-733.

Fowler, S.J., Spera, F.J., 2008. Phase equilibria trigger for explosive volcanic eruptions. Geophysical Research Letter 35, L08309.

Fowler, S.J., Spera, F.J., 2010. A metamodel for crustal magmatism: phase equilibria of giant ignimbrites. Journal of Petrology 51, 1783-1830. 
Fujimaki, H., Tatsumoto, M., Aoki, K.I., 1984. Partition coefficients of Hf, Zr, and REE between phenocrysts and groundmasses. Journal of Geophysical Research: Solid Earth, 89, B662-B672.

Ghiorso, M.S., Gualda, G.A., 2015. An $\mathrm{H}_{2} \mathrm{O}-\mathrm{CO}_{2}$ mixed fluid saturation model compatible with rhyolite-MELTS. Contributions to Mineralogy and Petrology 169, 53.

Ginibre, C., Wörner, G. 2007. Variable parent magmas and recharge regimes of the Parinacota magma system (N. Chile) revealed by Fe, Mg and $\mathrm{Sr}$ zoning in plagioclase. Lithos 98, 118-140.

Ginibre, C., Wörner, G., Kronz, A., 2002. Minor-and trace-element zoning in plagioclase: implications for magma chamber processes at Parinacota volcano, northern Chile. Contributions to Mineralogy and Petrology, 143, 300-315.

Ginibre, C., Wörner, G., Kronz, A., 2007. Crystal zoning as an archive for magma evolution. Elements, 3, 261-266.

Giordano, D., Russell, J.K., Dingwell, D.B., 2008. Viscosity of mag- matic liquids: A model. Earth Planetary Science Letters, 271, 123-134.

Gorshkov, G.S., Dubik, Y.M., 1970. Gigantic directed blast at Shiveluch volcano (Kamchatka). Bulletin of Volcanology 34, 261-288.

Gregg, P.M., Grosfils, E.B., de Silva, S.L., 2015. Catastrophic caldera-forming eruptions II: The subordinate role of magma buoyancy as an eruption trigger. Journal of Volcanology and Geothermal Research 305, 100-113.

Gualda G.A.R., Ghiorso M.S., Lemons R.V., Carley T.L., 2012- Rhyolite-MELTS: A modified calibration of MELTS optimized for silica-rich, fluid-bearing magmatic systems. Journal of Petrology 53, 875-890.

Gudmundsson, A., 2016. The mechanics of large volcanic eruptions. Earth-Science Reviews 163, $72-93$ 
Hall, M., Ramón, P., Mothes, P., LePennec, J. L., García, A., Samaniego, P., Yepes, H., 2004. Volcanic eruptions with little warning: the case of Volcán Reventador's Surprise November 3, 2002 Eruption, Ecuador. Revista geológica de Chile 31, 349-358.

Harlow, D.H., Power, J.A., Laguerta, E.P., Ambubuyog, G., White, R.A., Hoblitt, R.P., 1996. Precursory seismicity and forecasting of the June 15, 1991, eruption of Mount Pinatubo. Fire and Mud: eruptions and lahars of Mount Pinatubo, Philippines, 223-247.

Higgins, M.D., 2000. Measurements of crystal size distributions. American Mineralogist 85, $1105-1116$.

Higgins, M.D., 2002. Closure in crystal size distributions (CSD), verifica- tion of CSD calculations, and the significance of CSD fans. American Mineralogist 87, 171-175.

Houghton, B.F., Wilson, C.J.N., Del Carlo, P., Coltelli, M., Sable, J.E., Carey, R., 2004. The influence of conduit processes on changes in style of basaltic Plinian eruptions: Tarawera 1886 and Etna 122 BC. Journal of Volcanology and Geothermal Research 137, 1-14.

Johnson, D.J., Sigmundsson, F., Delaney, P.T., 2000. Comment on "Volume of magma accumulation or withdrawal estimated from surface uplift or subsidence, with application to the 1960 collapse of K1lauea volcano" by P. T. Delaney and D. F. McTigue. Bulletin of Volcanology (2000) 61, 491-493.

Linde, A.T., Sacks, I.S., 1998. Triggering of volcanic eruptions. Nature 395, 888-890.

Lipman, P.W., Mullineaux, D.R., 1981. The 1980 eruptions of Mount St. Helens, Washington (No. 1250). US Dept. of the Interior, US Geological Survey.

Leonard, G.S., Cole, J.W., Nairn, I.A., Self, S., 2002. Basalt triggering of the c. AD 1305 Kaharoa rhyolite eruption, Tarawera volcanic complex, New Zealand. Journal of Volcanology and Geothermal Research 115, 461-486.

Long, D.A., 1977. Raman Spectroscopy. Mcgraw-Hill, 2, pp. 276. 
Longerich, H.P., Jackson, S.E., Gunther, D., 1997. Laser ablation inductively coupled plasma mass spectrometric transient signal data acquisition and analyte concentration calculation (vol 11, 899, 1996). Journal of Analytical Atomic Spectrometry, 12, 391-391.

Macías, J.L., Sosa-Ceballos, G., Arce, J.L., Gardner, J.E., Saucedo, R., Valdez-Moreno, G., 2017. Storage conditions and magma processes triggering the 1818CE Plinian eruption of Volcán de Colima. Journal of Volcanology and Geothermal Research 340, 117-129.

Malfait, W.J., Seifert, R., Petitgirard, S., Perrillat, J., Mezouar, M., De Gãl, L., Bernard, U.C., 2014. Supervolcano eruptions driven by melt buoyancy in large silicic magma chambers. Nature Geoscience 7, 122-125.

Massare, D., Métrich, N., Clocchiatti, R. 2002. High-temperature experiments on silicate melt inclusions in olivine at 1 atm: inference on temperatures of homogenization and $\mathrm{H} 2 \mathrm{O}$ concentrations. Chemical Geology, 183, 87-98.

Moore, G., Vennemann, T., Carmichael, I.S.E., 1998. An empirical model for solubility of $\mathrm{H}_{2} \mathrm{O}$ in magmas to 3 kilobars. American Mineralogist 83, 36-42.

Morgado, E., Morgan, D.J., Harvey, J., Parada, M.A., Castruccio, A., Brahm, R., Gutierrez, F., Georgiev, B., Hammond, S.J. 2019. Localised heating and magmatic intensive conditions prior to the 22-23 April 2015 Calbuco volcano eruption (Southern Chile). Bulletin of Volcanology.

Neave, D.A., Hartley, M.E., Maclennan, J., Edmonds, M., Thordarson, T., 2017. Volatile and light lithophile elements in high-anorthite plagioclase-hosted melt inclusions from Iceland. Geochimica et Cosmochimica Acta 205, 100-118.

Neave, D.A., Putirka, K.D., 2017. A new clinopyroxene-liquid barometer, and implications for magma storage pressures under Icelandic rift zones. American Mineralogist 102, 777-794.

Neuman, H., Mead, J., Vitaliano, C.J., 1954. Trace-element variation during crystallization as calculated from the distribution law. Geochimica Cosmochimica Acta 6, 90-100. 
Pallister, J.S., Hoblitt, R.P., Reyes, A.G., 1992. A basalt trigger for the 1991 eruptions of Pinatubo volcano? Nature 356, 426-428.

Pardini, F., Burton, M., Arzilli, F., La Spina, G., Polacci, M., 2018. $\mathrm{SO}_{2}$ emissions, plume heights and magmatic processes inferred from satellite data: the 2015 Calbuco eruptions. Journal of Volcanology and Geothermal Research 361, 12-24.

Petrelli, M., Laeger, K., Perugini, D., 2016. High spatial resolution trace element determination of geological samples by laser ablation quadrupole plasma mass spectrometry: Implications for glass analysis in volcanic products. Geosciences Journal 20, 851-863.

Petrelli, M., Poli, G., Perugini, D., Peccerillo, A., 2005. PetroGraph: A new software to visualize, model, and present geochemical data in igneous petrology, Geochemistry Geophysics Geosystems 6, Q07011.

Potts, P.J., Webb, P.C., 1992. X-ray fluorescence spectrometry. Journal of Geochemical Exploration 44, 251-296.

Putirka, K.D., 2008. Thermometers and barometers for volcanic systems. Reviews in Mineralogy and Geochemistry 69, 61-120.

Rivera, M., Anieri, M., Amelung, F., Mothes, P., Hong, S.H., Nocquet, J.M., Jarrin, P., 2017. Ground deformation before the 2015 eruptions of Cotopaxi volcano detected by InSAR. Geophysical Research Letters 44, 6607-6615.

Rocholl, A., 1998. Major and Trace Element Composition and Homogeneity of Microbeam Reference Material: Basalt Glass USGS BCR-2G. Geostandards and Geoanalytical Research $22,33-45$.

Romero, J.E., Morgavi, D., Arzilli, F., Daga, R., Caselli, A., Reckziegel, F., Viramonte, J., DíazAlvarado, J., Polacci, M., Burton, M., Perugini, D., 2016. Eruption dynamics of the 22-23 April 2015 calbuco volcano (Southern Chile): Analyses of tephra fall deposits. Journal of Volcanology and Geothermal Research 317, 15-29. 
Ruprecht, P., Wörner, G., 2007. Variable regimes in magma systems documented in plagioclase zoning patterns: El Misti stratovolcano and Andahua monogenetic cones. Journal of Volcanology and Geothermal Research, 165, 142-162.

Scandone, R., 1996. Factors controlling the temporal evolution of explosive eruptions. Journal of volcanology and geothermal research 72, 71-83.

Segall, P., 2013. Volcano deformation and eruption forecasting. Geological Society, London, Special Publications 380, 85-106.

SERNAGEOMIN, 2015. Reporte Especial de Actividad Volcánica (REAV) Región de los Lagos. Año 2015. http://www.sernageomin.cl/

Shea, T., Hammer, J.E., 2013. Kinetics of cooling- and decompression-induced crystallization in hydrous mafic-intermediate magmas. Journal of Volcanology and Geothermal Research 260, $127-145$.

Shea, T., Larsen, J. F., Gurioli, L., Hammer, J. E., Houghton, B. F., Cioni, R., 2009. Leucite crystals: surviving witnesses of magmatic processes preceding the 79AD eruption at Vesuvius, Italy. Earth and Planetary Science Letters 281, 88-98.

Sigmundsson, F., Hreinsdóttir, S., Hooper, A., Árnadóttir, T., Pedersen, R., Roberts, M.J., Óskarsson, N., Auriac, A., Decriem, J., Einarsson, P., Geirsson, H., Hensch, M., Ófeigsson, B.G., Sturkell, E., Sveinbjörnsson, H., Feigl, K.L., 2010. Intrusion triggering of the 2010 Eyjafjallajökull explosive eruption. Nature 468, 426-430.

Signorelli, S., Vaggelli, G., Francalanci, L., Rosi, M., 1999. Origin of magmas feeding the Plinian phase of the Campanian Ignimbrite eruption, Phlegrean Fields (Italy): constraints based on matrix-glass and glass-inclusion compositions. Journal of Volcanology and Geothermal Research 91, 199-220.

Sparks, R.S.J., 2003. Forecasting volcanic eruptions. Earth and Planetary Science Letters 210, 115. 
Sparks, S.R., Sigurdsson, H., Wilson, L., 1977. Magma mixing: a mechanism for triggering acid explosive eruptions. Nature 267, 315-318.

Steele-MacInnis, M., Esposito, R., Moore, L.R., Hartley, M.E., 2017. Heterogeneously entrapped, vapor-rich melt inclusions record pre-eruptive magmatic volatile contents. Contributions to Mineralogy and Petrology, 172, 18.

Stock, M.J., Humphreys, M.C., Smith, V.C., Isaia, R., Pyle, D.M., 2016. Late-stage volatile saturation as a potential trigger for explosive volcanic eruptions. Nature Geoscience 9, 249-254.

Stock, M.J., Taylor, R.N., Gernon, T.M., 2012. Triggering of major eruptions recorded by actively forming cumulates. Scientific Reports 2, 731.

Szramek, L., Gardner, J.E., Larsen, J., 2006. Degassing and microlite crystallization of basaltic andesite magma erupting at Arenal Volcano, Costa Rica. Journal of Volcanology and Geothermal Research 157, 182-201.

Tait, S., Jaupart, C., Vergniolle, S., 1989. Pressure, gas content and eruption periodicity of a shallow, crystallising magma chamber. Earth and Planetary Science Letters 92, 107-123.

Tarasewicz, J., White, R.S., Brandsdóttir, B., Schoonman, C.M., 2014. Seismogenic magma intrusion before the 2010 eruption of Eyjafjallajökull volcano, Iceland. Geophysical Journal International 198, 906-921.

Tramontano, S., Gualda, G.A., Ghiorso, M.S., 2017. Internal triggering of volcanic eruptions: tracking overpressure regimes for giant magma bodies. Earth and Planetary Science Letters $472,142-151$.

Valderrama, O., Franco, L., Gil-Cruz, F., 2015. Erupción intempestiva del volcán Calbuco, abril 2015. XIV Congreso Geológico Chileno, La Serena. Abstracts.

Van Eaton, A., Amigo, A., Bertin, D., Mastin, L., Giacosa, R., González, J., Valderrama, O., Fontijn, K., Behnke, S., 2016. Volcanic lightning and plume behavior reveal evolving hazards 
during the April 2015 eruption of Calbuco volcano, Chile. Geophysical Research Letters 43, $3563-3571$.

Vona, A., Romano, C., Dingwell, D.B., Giordano, D., 2011. The rheology of crystal-bearing basaltic magmas from Stromboli and Etna. Geochimica Cosmochimica Acta 75, 3214-3236.

Walker, G.P., 1980. The Taupo pumice: product of the most powerful known (ultraplinian) eruption? Journal of Volcanology and Geothermal Research 8, 69-94.

Walker, G.P., Self, S., Wilson, L., 1984. Tarawera 1886, New Zealand - a basaltic plinian fissure eruption. Journal of Volcanology and Geothermal Research 21, 61-78.

Waters, L., Lange, R., 2015. An updated calibration of the plagioclase- liquid hygrometerthermometer applicable to basalts through rhyolites. American Mineralogist 100, 2172-2184.

Wehrmann, H., Freundt, A., Kutterolf, S., 2016. The 12.4 ka Upper Apoyeque Tephra, Nicaragua: stratigraphy, dispersal, composition, magma reservoir conditions and trigger of the plinian eruption. Bulletin of Volcanology 78, 44.

Williams, S.N., Self, S., 1983. The October 1902 plinian eruption of Santa Maria volcano, Guatemala. Journal of Volcanology and Geothermal Research 16, 33-56.

\section{Figure captions}

Figure 1. Stratigraphy of the tephra fall deposit from the 2015 Calbuco eruption, and textural features of scoriae. Left: schematic stratigraphy (not to scale) of the DF10 proximal deposit showing the four units of the tephra fall deposit (re-drawn after Romero et al., 2016). Unit A is the tephra fall deposit of the first phase of the eruption on 22 April 2015. Units B, C and D are the deposits of the second phase on 23 April 2015. Bulk textures of typical scoria clasts from each unit are shown in BSE images at the centre, while details of the groundmass (plagioclase and pyroxene microlites and the glassy matrix) are shown on the right. 
Figure 2. Textural features of glassy matrices in scoriae from units A, B, C and D showing skeletal plagioclase and pyroxene microlites $<15 \mu \mathrm{m}$.

Figure 3. Crystal size distributions (CSDs) of Calbuco scoriae derived by CSDCorrections 1.6 software (Higgins 2000, 2002).

Figure 4. BSE images of plagioclase zoning textures. (a) Plagioclase phenocryst characterised by a large core with normal zoning and an overgrowth rim with oscillatory zoning. (b-c-d) Plagioclase phenocrysts characterised by a large overgrowth rim with oscillatory zoning, in which several resorption and regrowth layers can be observed. Red arrows in (c) indicate the last resorption event. (e-f) Overgrowth rims can be characterised by sieve textures (e) and patchy zoning textures (e-f), in which melt inclusions can be hosted.

Figure 5. Harker-style diagrams of major element compositional variability in products from the 2015 Calbuco eruption: bulk composition of juvenile scoriae, plagioclase-hosted melt inclusions, and matrix glass. Plagioclase-hosted melt inclusions were corrected for postentrapment crystallisation following the method of Neave et al. (2017). The diagram reports chemical data collected for each unit (A, B, C and D).

Figure 6. Trace element variability measured in the bulk rock, plagioclase-hosted melt inclusions, and matrix glass of products from the 2015 Calbuco eruption. Melt differentiation trends driven by fractional crystallisation are modelled assuming the mean bulk rock composition of juvenile scoriae as the starting composition. The melt fraction was varied from 0.47 to 1 . For the fractional crystallisation model the bulk partition coefficient $\left(D^{b}\right)$ of $\mathrm{Zr}$ ranges 
between 0.1 and $0.15, D^{b}{ }_{\mathrm{Rb}}$ is $0.06(\mathrm{a}), D_{\mathrm{Sr}}^{b}$ is between 1.2 and $1.75(\mathrm{~b}), D^{b}{ }_{\mathrm{Y}}$ is $0.25(\mathrm{c}), D^{b}{ }_{\mathrm{Nb}}$ is 0.05 (d), $D_{\text {Ba }}^{b}$ is 0.4 (e) and $D_{\text {La }}^{b}$ is 0.1 (f) (Fujimaki et al., 1984; Dunn and Sen, 1994; AignerTorres et al., 2007). The ticks along the fractional crystallisation path indicate the melt fraction (each tick is 0.1 ).

Figure 7. (a) Anorthite contents of plagioclase crystals in the scoriae of the 2015 Calbuco eruption, showing the compositions of phenocrysts (cores, overgrowth with oscillatory zones and external rims) and microlites. Kernel density distributions for the plagioclase populations are reported as solid line. (b) Compositions of pyroxene crystals in Calbuco scoriae, Di: diopside; Hd: hedenbergite; En: enstatite; Fs: ferrosilite. (c) Compositions of olivine crystals in Calbuco scoriae. All diagrams report mineral compositions from each tephra fall unit (A, B, C and D).

Figure 8. Electron microprobe quantitative point analysis profiles across plagioclase crystals from core to rim. Profile for $\mathrm{An}(\mathrm{mol} . \%), \mathrm{FeO}$ (wt.\%) and $\mathrm{MgO}$ (wt.\%) are reported in the figure: (a-b) plagioclase \#8 of unit A; (c-d) plagioclase \#12 of unit C; (e-f) plagioclase \#6 of unit D.

Figure 9. (a) $\mathrm{H}_{2} \mathrm{O}$ dissolved in melt inclusions (MI) hosted in orthopyroxene, clinopyroxene, and plagioclase crystals, measured by Raman spectroscopy. Kernel density distributions for $\mathrm{H}_{2} \mathrm{O}$ dissolved in MIs are reported. (b) $\mathrm{H}_{2} \mathrm{O}$ solubility in basaltic andesitic and andesitic melts as a function of pressure, calculated following Moore et al. (1998). Basaltic andesite is the bulk composition erupted during the 2015 Calbuco eruption; andesite is the composition of plagioclase-hosted melt inclusions and represents the pre-eruptive melt composition. 
Figure 10. Pre-eruptive conditions of the 2015 Calbuco eruption. (a) The orthopyroxeneliquid thermometer (Putirka, 2008) was used to estimate the crystallisation temperatures of orthopyroxene phenocrysts. Pre-eruptive temperatures for cores and blocky microlites were obtained using the plagioclase-liquid thermometer of Putirka (2008) and the plagioclase-liquid hygrometer-thermometer of Waters and Lange (2015). The range of pre-eruptive pressures was predicted with Rhyolite-MELTS software (version 1.2) (Ghiorso et al. 2012; Ghiorso and Gualda, 2015), investigating the highest amount of $\mathrm{H}_{2} \mathrm{O}\left(5.5\right.$ to 6.5 wt. $\left.\% \mathrm{H}_{2} \mathrm{O}\right)$ measured in pyroxene- and plagioclase-hosted MIs and the temperatures obtained from mineral-liquid thermometers. P2008: Putirka, 2008. W\&L2015: Waters and Lange, 2015. The $1 \sigma$ calibration uncertainty on the Putirka (2008) thermometer is $\pm 48^{\circ} \mathrm{C}$. The Waters and Lange (2015) hygrometer has a $1 \sigma$ temperature uncertainty of $\pm 12{ }^{\circ} \mathrm{C}$. The red horizontal bar shows the pressure range of the major volcanotectonic (VT) earthquakes that preceded the eruption. (b) Rhyolite-MELTS simulations indicate that the plagioclase crystal fraction $\left(\phi_{\mathrm{Pl}}\right)$ ranges between 0.10 and 0.35 at the pre-eruptive conditions, in agreement with $\phi_{\mathrm{Pl}}$ calculated in the natural scoriae produced from the 2015 Calbuco sub-Plinian eruption. The plagioclase liquidus in $\mathrm{H}_{2} \mathrm{O}-$ saturated basaltic andesite magma has been obtained from Shea and Hammer (2013).

Figure 11. Localization depths of major volcanotectonic (VT) earthquakes at Calbuco reported in monthly (diamond), daily (dots), and bi-weekly (square) reports from SERNAGEOMIN (available at http://www.sernageomin.cl/) during 2015. The colour bar indicates the number of events. The volcano was monitored by five seismometers, with the closest station $5 \mathrm{~km}$ to the west. 
Table 1: Crystal fraction of Calbuco scoriae of the DF10 proximal deposit.

\begin{tabular}{|c|c|c|c|c|c|c|c|c|c|c|}
\hline \multirow[t]{2}{*}{ Sample } & \multicolumn{3}{|c|}{$\begin{array}{l}\text { Texture with crystals } \\
>250 \mu \mathrm{m}\end{array}$} & \multicolumn{3}{|c|}{$\begin{array}{l}\text { Groundmass with } \\
\text { crystals }<250 \mu \mathrm{m}\end{array}$} & \multicolumn{4}{|c|}{ Total phases } \\
\hline & $\phi \mathrm{Pl}$ & $\begin{array}{c}\phi \mathrm{Px} \\
(\mathrm{Opx}+\mathrm{Cpx}) \\
\end{array}$ & $\phi$ Ti-Mag & $\begin{array}{c}\phi \mathrm{Pl} \\
\text { microlite }\end{array}$ & $\begin{array}{c}\phi \mathrm{Px} \\
\text { microlite }\end{array}$ & $\phi \mathrm{gl}$ & $\phi \mathrm{Pl}$ & $\begin{array}{c}\phi \mathrm{Px} \\
(\mathrm{Opx}+\mathrm{Cpx}) \\
\end{array}$ & $\phi$ Ti-Mag & $\phi \mathrm{gl}$ \\
\hline DF10A & 0.24 & 0.09 & 0.01 & 0.21 & 0.04 & 0.40 & 0.46 & 0.14 & 0.01 & 0.40 \\
\hline DF10B & 0.24 & 0.09 & 0.01 & 0.19 & 0.03 & 0.44 & 0.43 & 0.12 & 0.01 & 0.44 \\
\hline DF10C & 0.23 & 0.07 & 0.01 & 0.17 & $<<0.01$ & 0.52 & 0.40 & 0.07 & 0.01 & 0.52 \\
\hline DF10D & 0.27 & 0.07 & 0.01 & 0.20 & 0.04 & 0.40 & 0.47 & 0.11 & 0.01 & 0.40 \\
\hline
\end{tabular}

note: the crystal fraction $(\phi)$ of each phase is calculated on a vesicle-free basis. Texture with crystals $>200 \mu \mathrm{m}$ includes phenocrysts (generally from $\sim 250$ to $\sim 1500 \mu \mathrm{m}$ ). Groundmass with crystals $<250 \mu \mathrm{m}$ includes microlites (from 1 to $\sim 250 \mu \mathrm{m}$ ) and patches of glass (residual melt). In the groundmass $\phi$ Ti-Mag is $<<0.01$. The crystal fraction of olivine crystals is $<0.01$ and it is included in $\phi \mathrm{Px}$. Pl: plagioclase; Px: pyroxene; Opx: orthopyroxene; Cpx: clinopyroxene; Ti-Mag: titanomagnetite; gl: glass. 


\section{Highlights}

Pre-eruptive conditions of the 2015 Calbuco eruption have been constrained

Sub-Plinian eruptions can be triggered by over-pressure due to crystallisation

Sub-Plinian eruptions can be internally triggered in a few hours 


\section{DF10 Sequence}

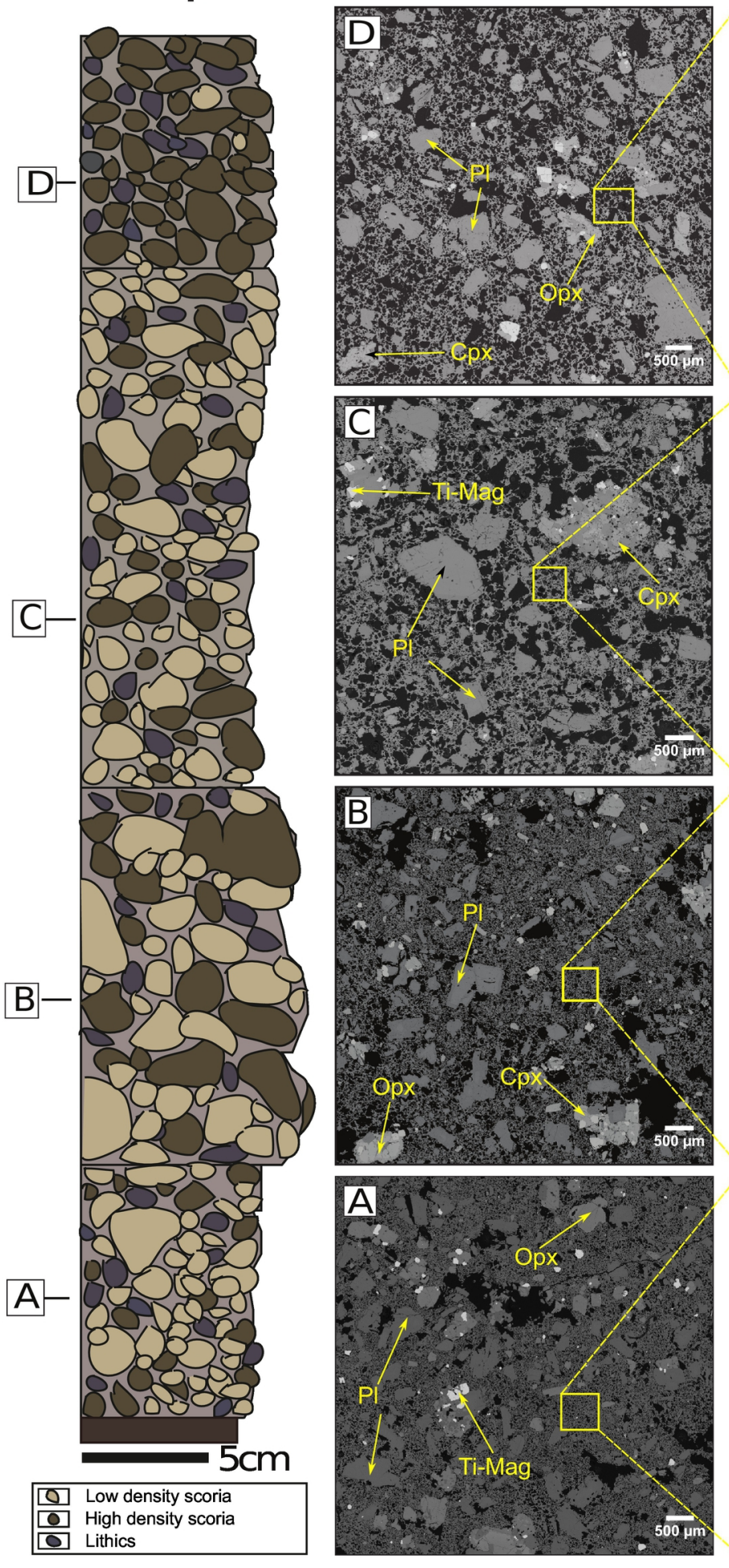

\section{Groundmass}
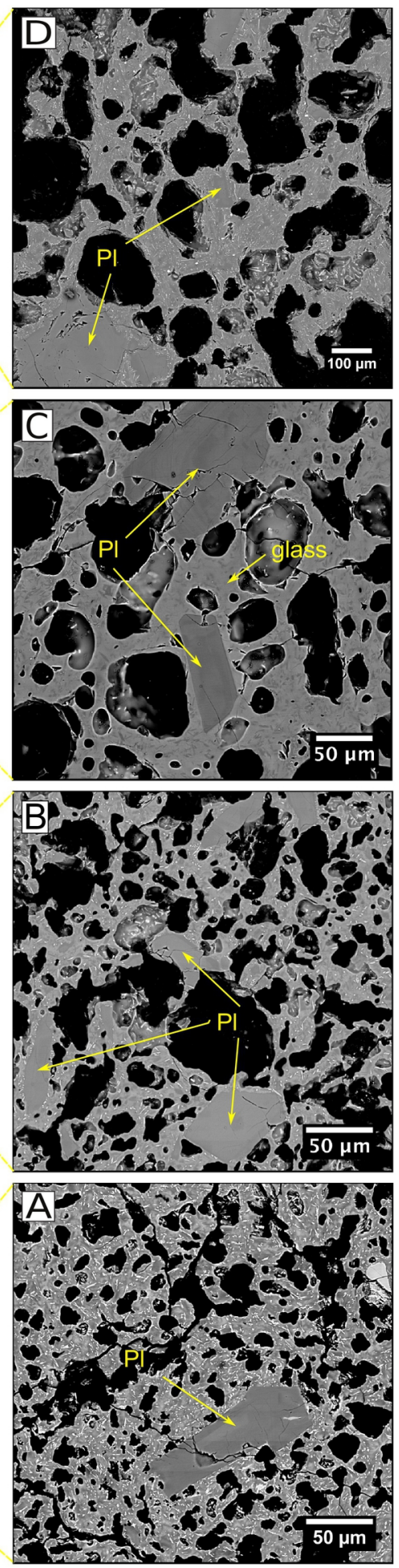

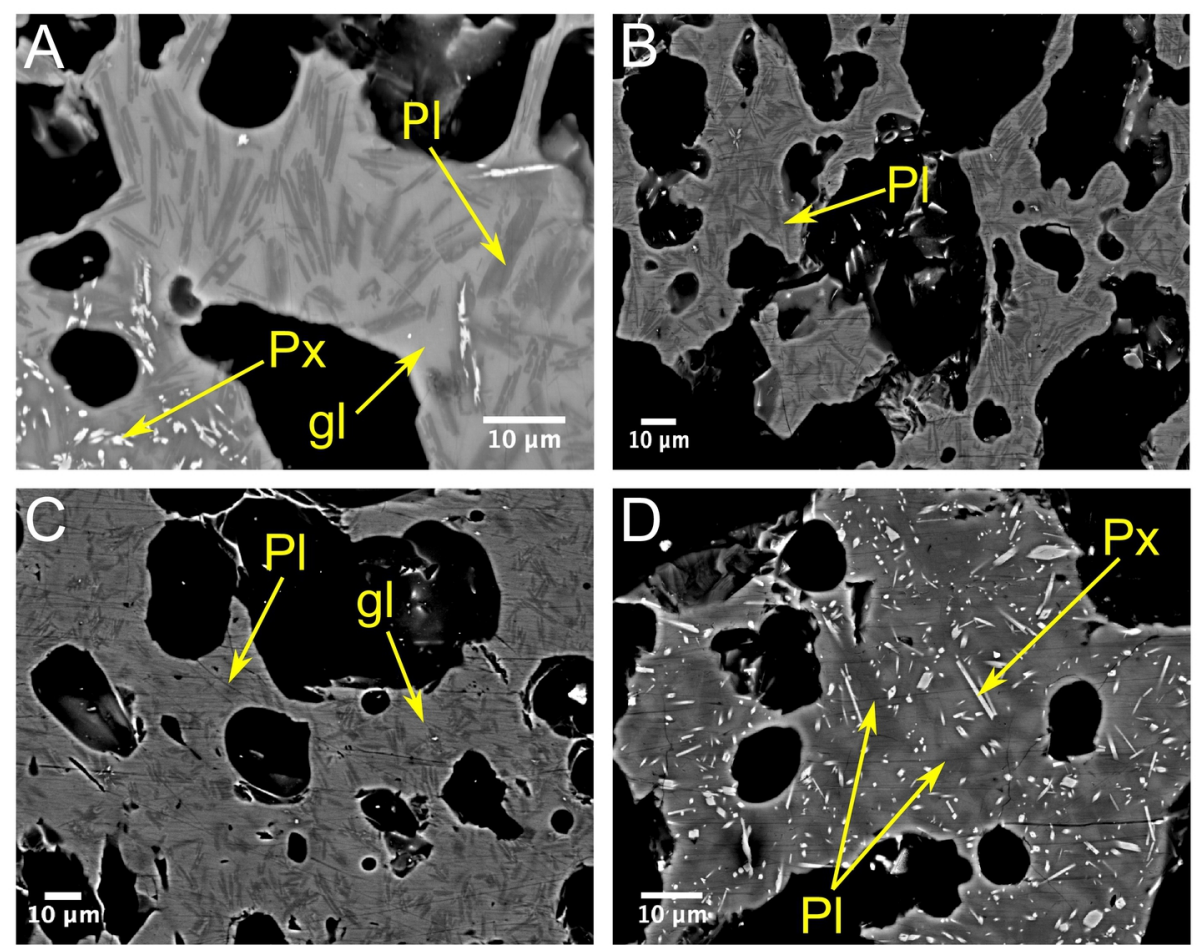

Figure 2 


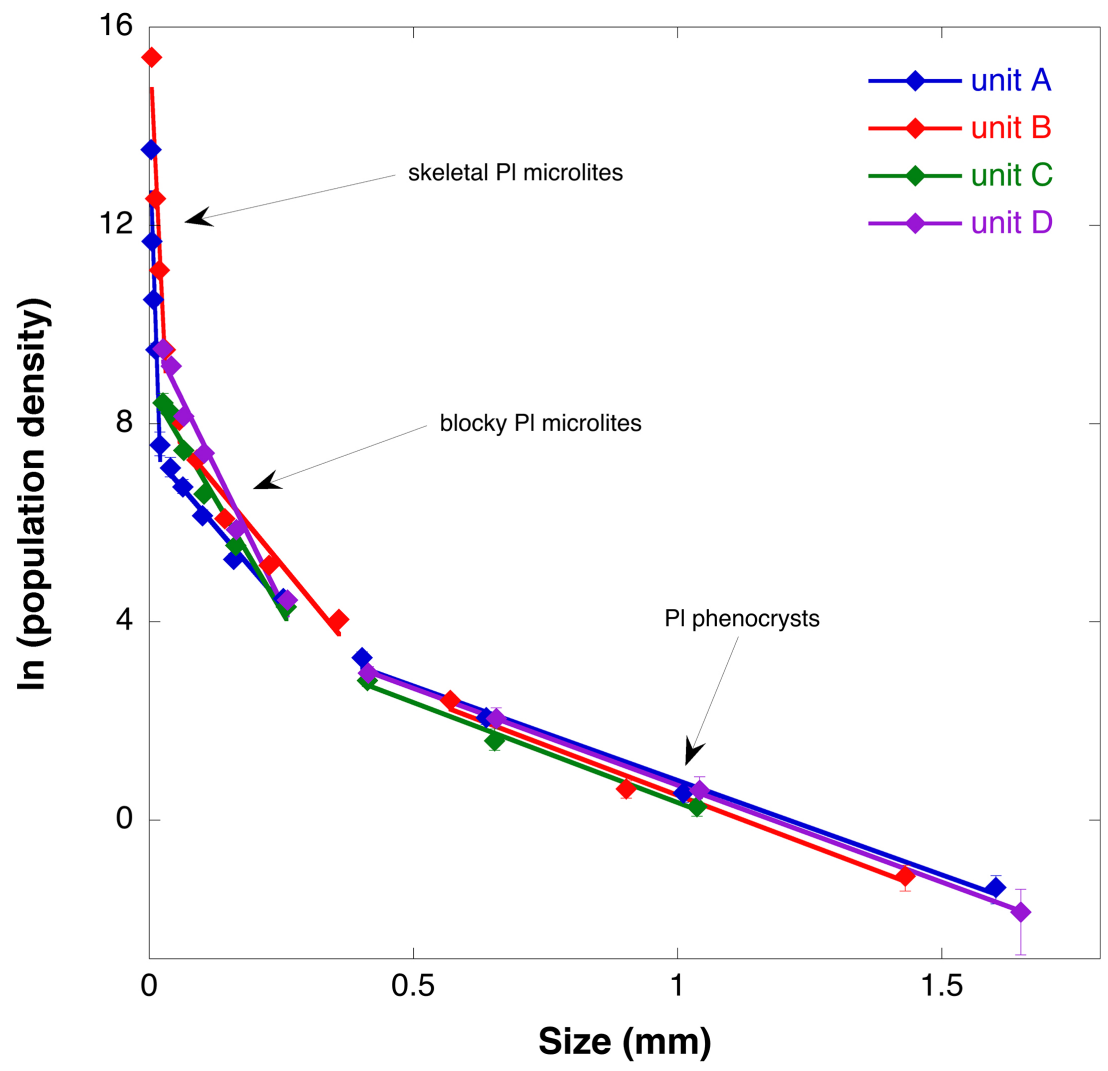

Figure 3 


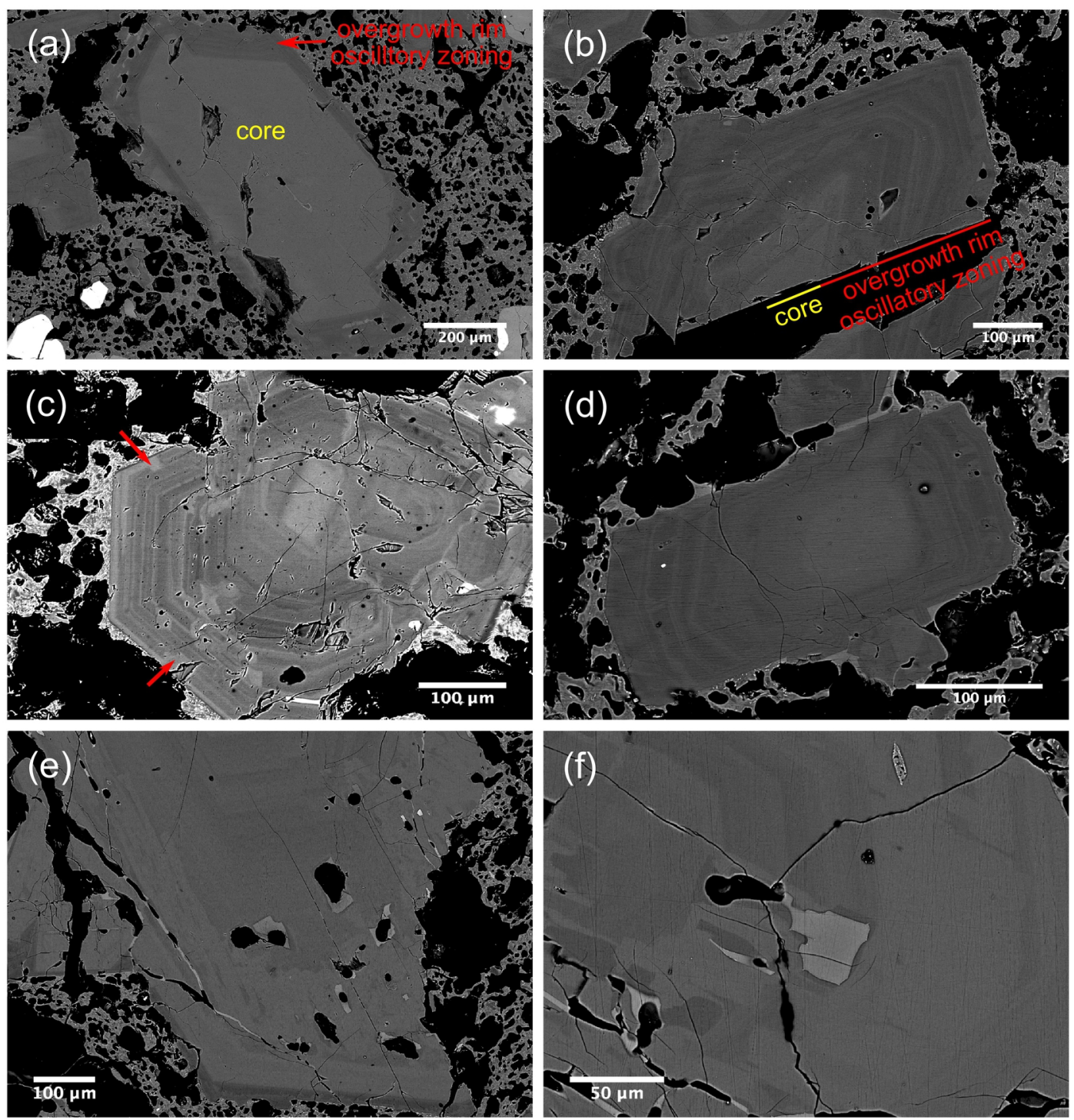

Figure 4 

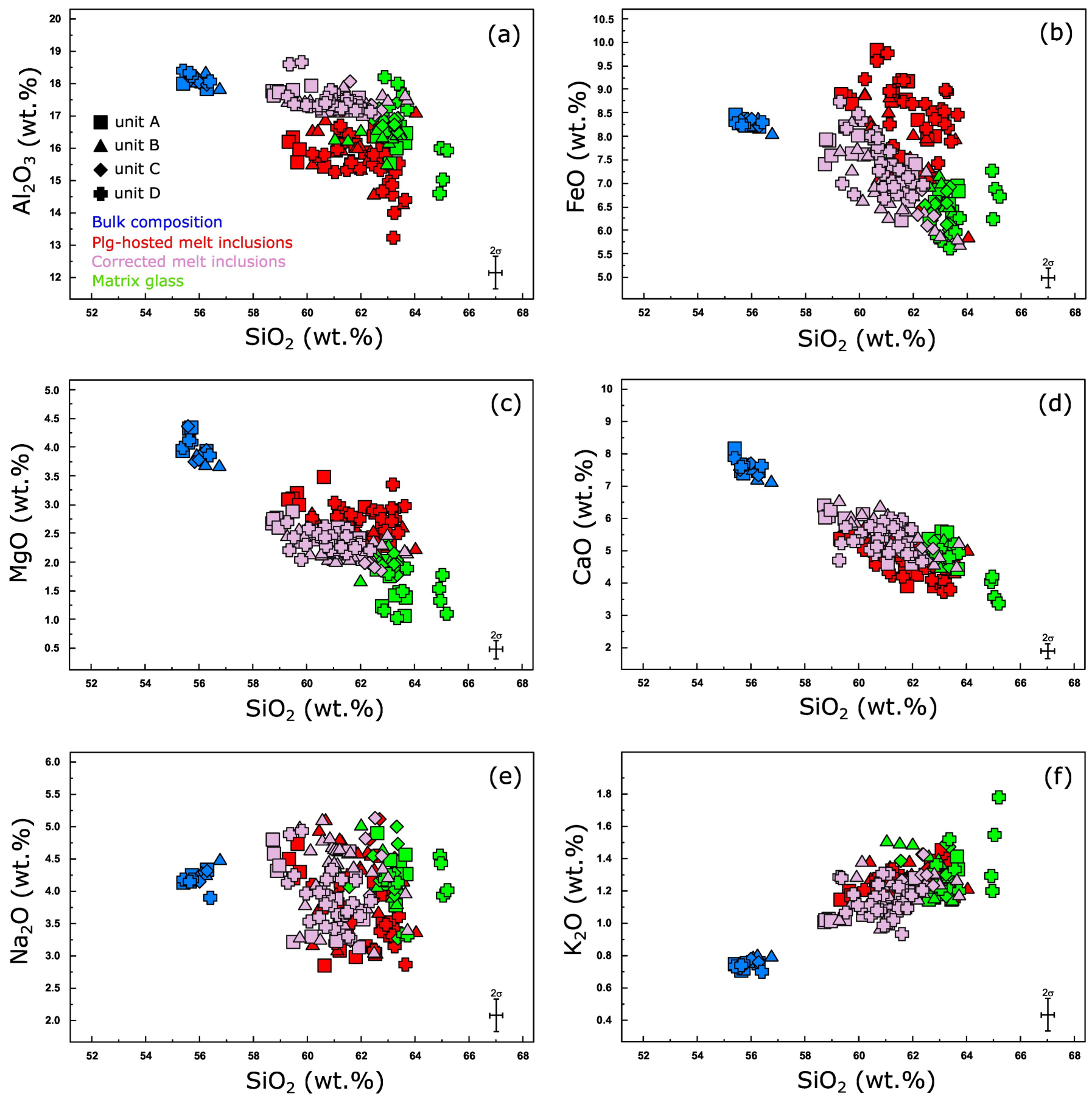

Figure 5 

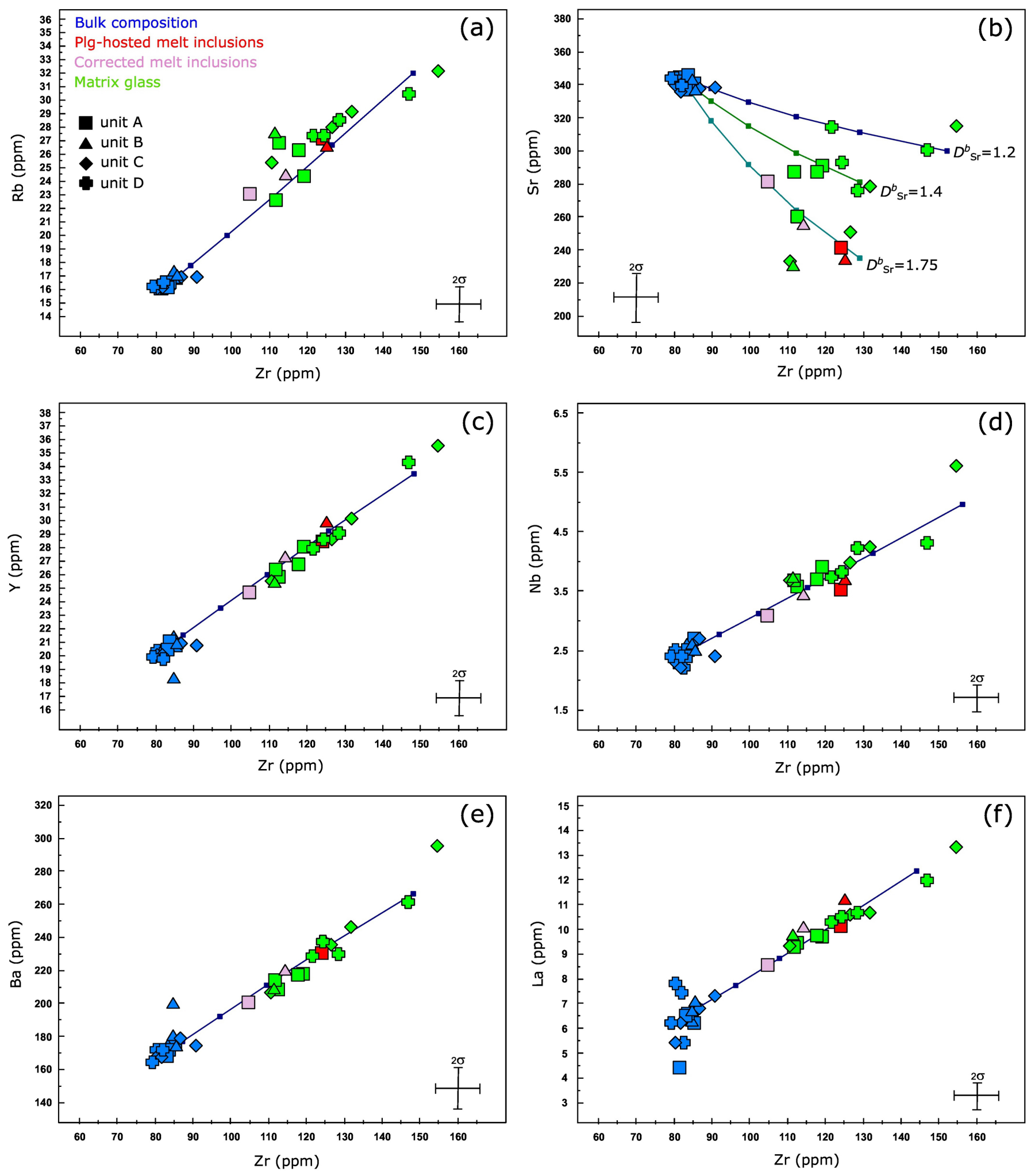

Figure 6 


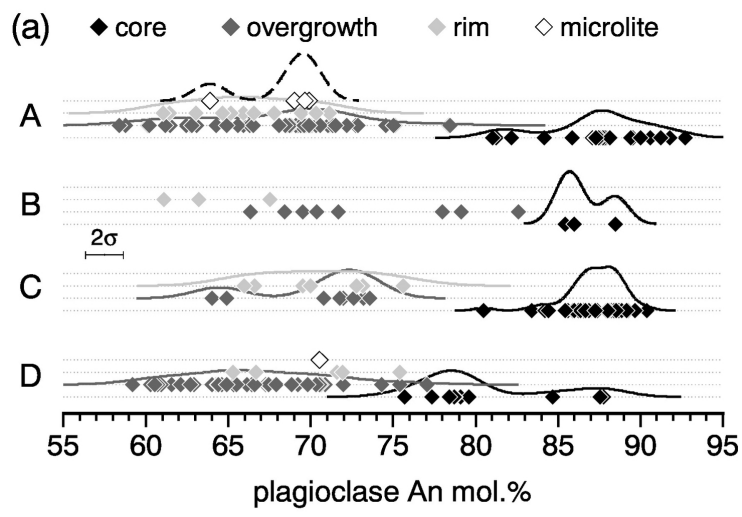

(b)

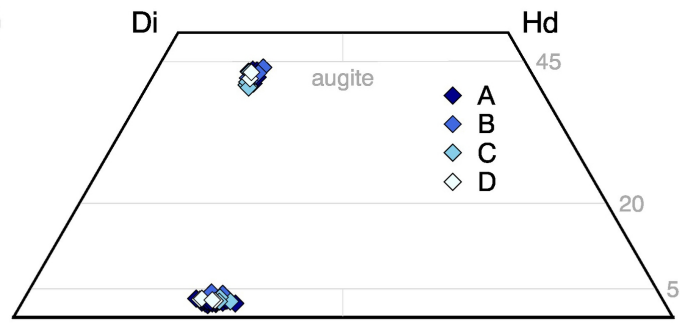

En

Fs

(c)

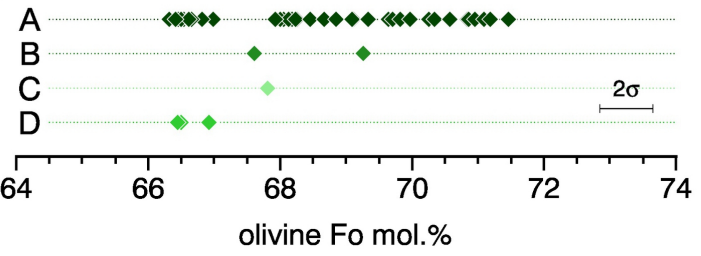

Figure 7 

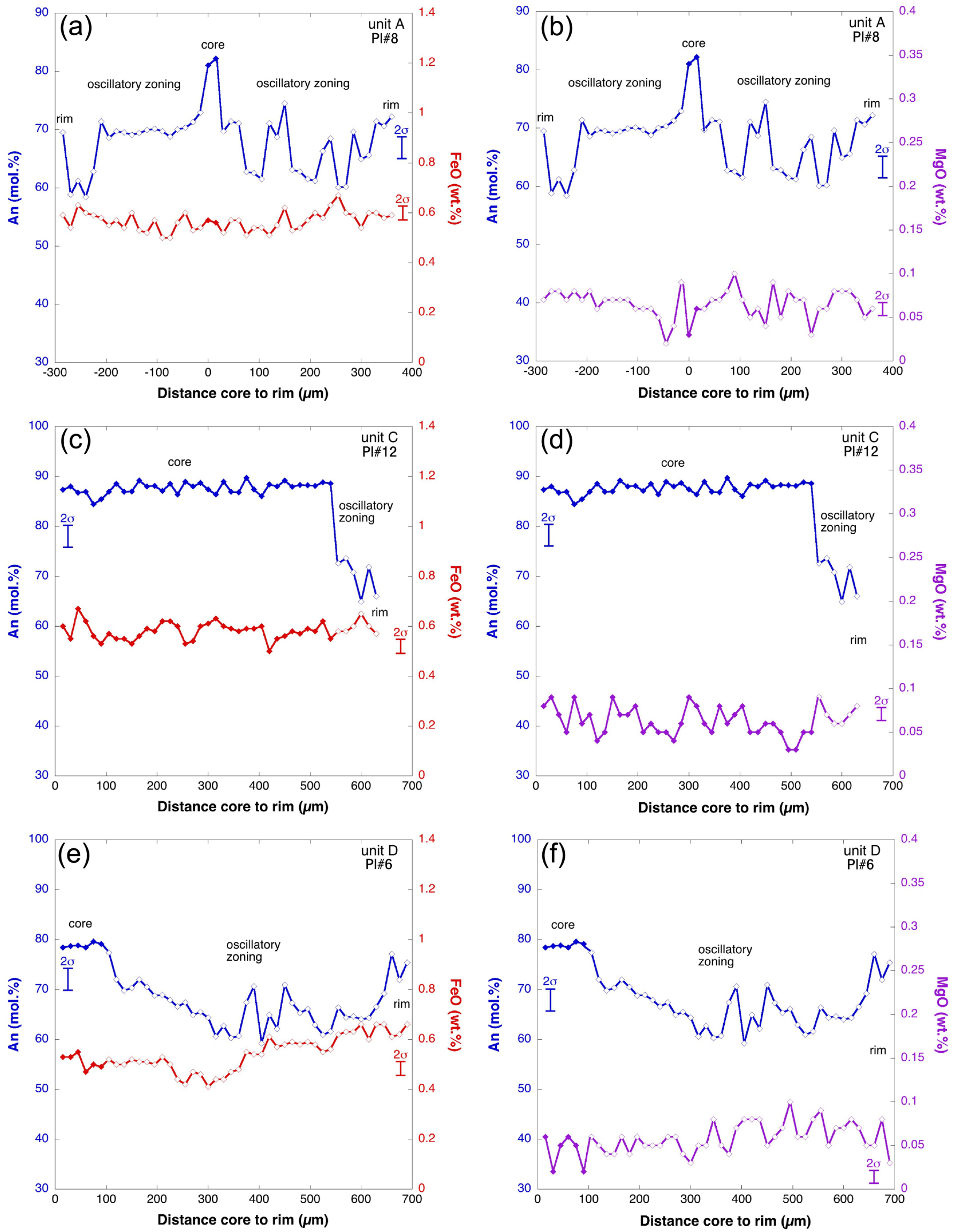

Figure 8 

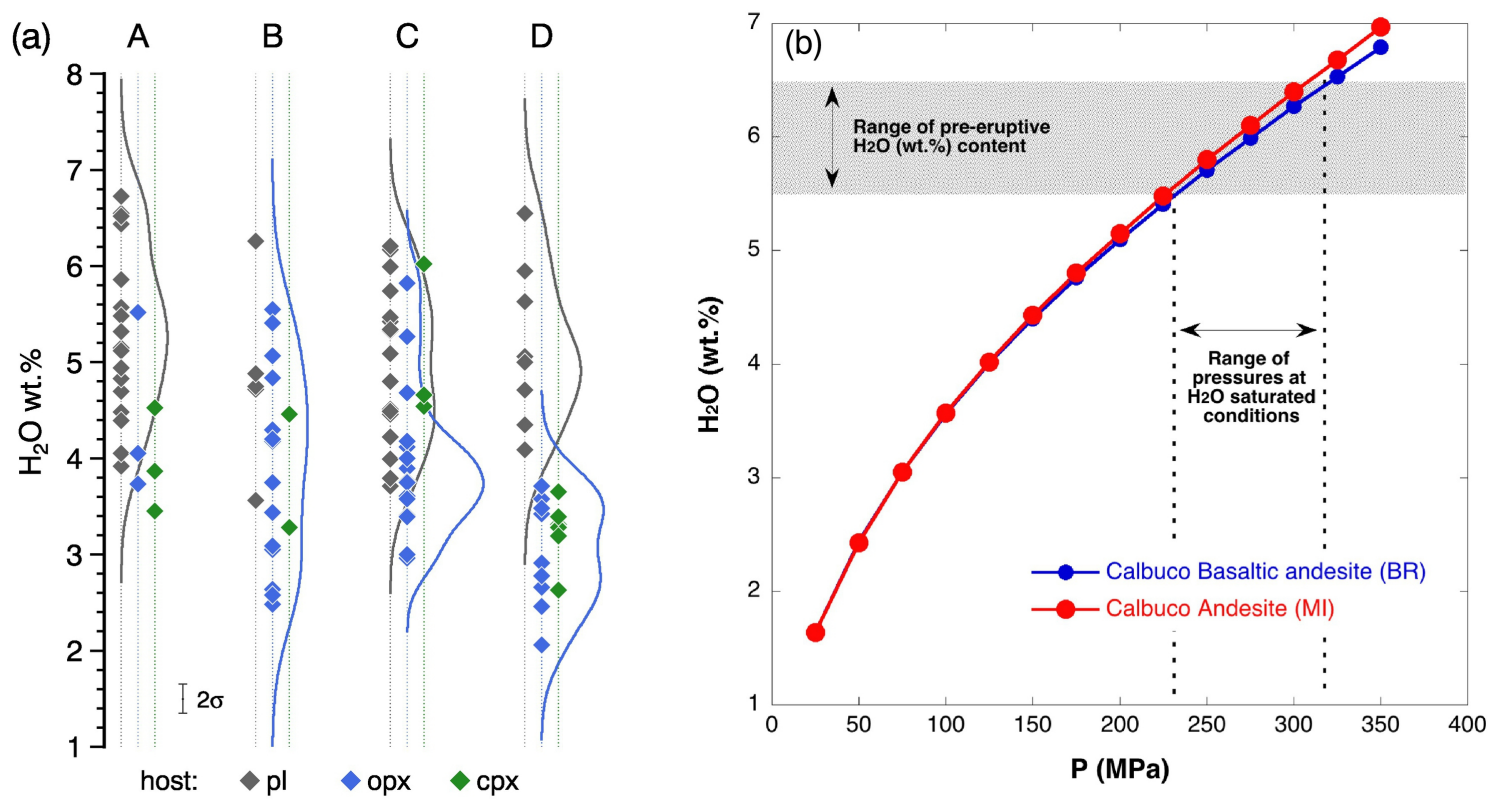

Figure 9 

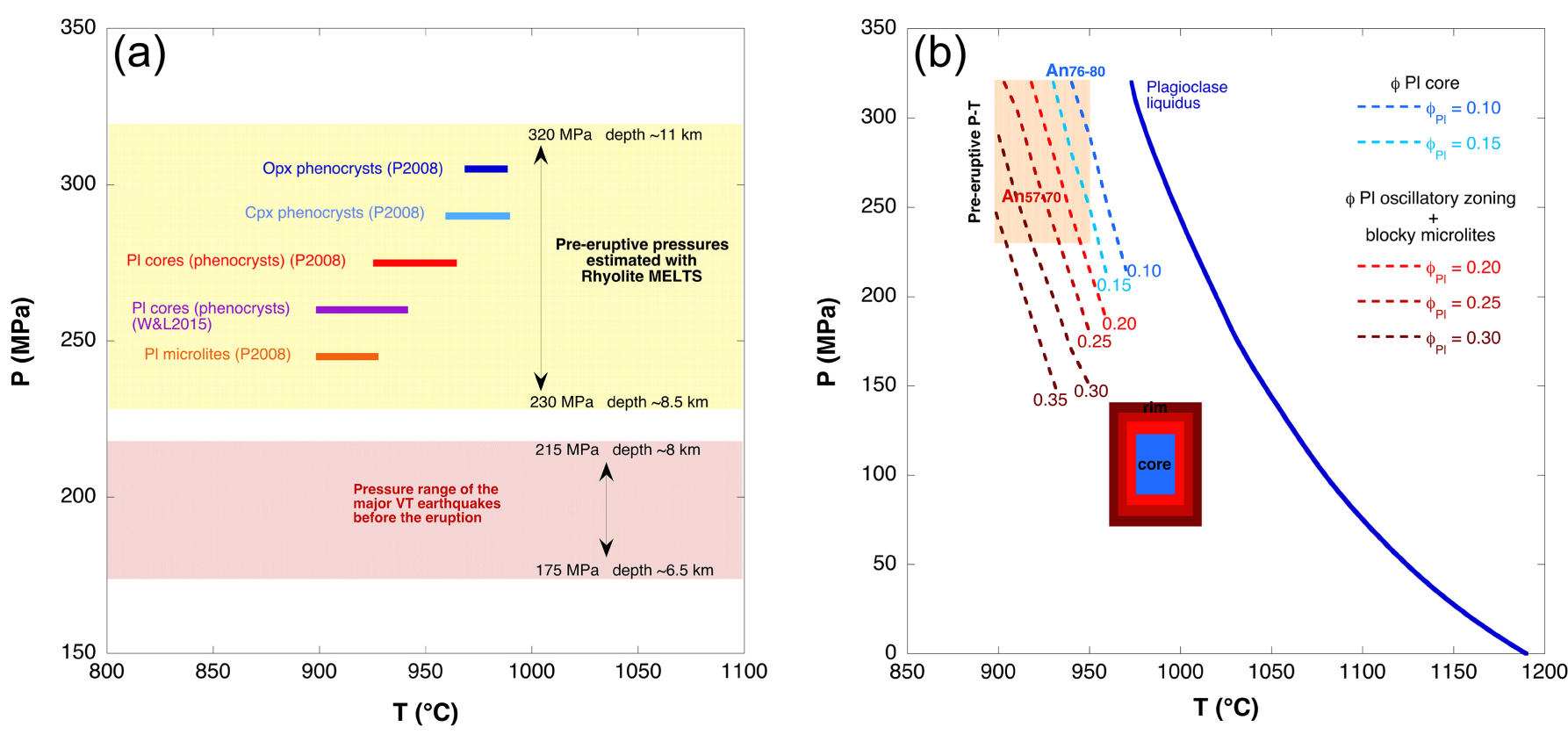


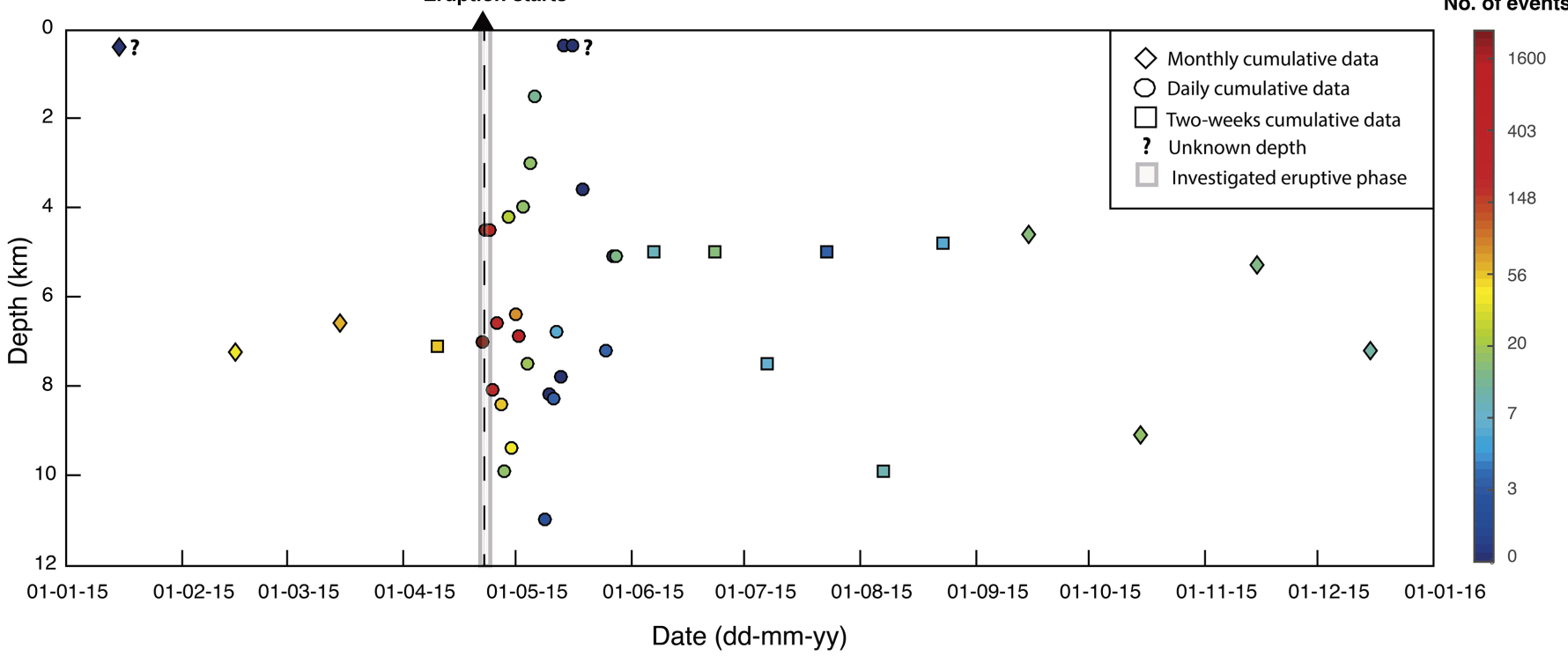

Figure 11 